\title{
Hippocampal Metaplasticity Is Required for the Formation of Temporal Associative Memories
}

\author{
Jian Xu, ${ }^{1}$ Marcia D. Antion, ${ }^{1}$ Toshihiro Nomura, ${ }^{1}$ Stephen Kraniotis, ${ }^{1}$ Yongling $\mathrm{Zhu},{ }^{1}$ and ${ }^{\circledR}$ Anis Contractor ${ }^{1,2}$ \\ ${ }^{1}$ Department of Physiology, Northwestern University Feinberg School of Medicine, and ${ }^{2}$ Department of Neurobiology, Weinberg College of Arts and \\ Sciences, Northwestern University, Chicago, Illinois 60611
}

Metaplasticity regulates the threshold for modification of synaptic strength and is an important regulator of learning rules; however, it is not known whether these cellular mechanisms for homeostatic regulation of synapses contribute to particular forms of learning. Conditional ablation of mGluR5 in CA1 pyramidal neurons resulted in the inability of low-frequency trains of afferent activation to prime synapses for subsequent theta burst potentiation. Priming-induced metaplasticity requires mGluR5-mediated mobilization of endocannabinoids during the priming train to induce long-term depression of inhibition (I-LTD). Mice lacking priming-induced plasticity had no deficit in spatial reference memory tasks, but were impaired in an associative task with a temporal component. Conversely, enhancing endocannabinoid signaling facilitated temporal associative memory acquisition and, after training animals in these tasks, ex vivo I-LTD was partially occluded and theta burst LTP was enhanced. Together, these results suggest a link between metaplasticity mechanisms in the hippocampus and the formation of temporal associative memories.

Key words: endocannabinoid; memory; metaplasticity; mGluR5

\section{Introduction}

It is widely held that Hebbian forms of plasticity underlie information storage in the CNS and thus are fundamental to learning and memory. Synaptic plasticity is tightly regulated by multiple mechanisms and under the control of processes termed metaplasticity that regulate synaptic potentiation through state dependence of the system. Metaplasticity ensures that prior activity in the network maintains the threshold for synaptic plasticity induction in the optimal range so that subsequent activity can bidirectionally modify synaptic strength (Abraham and Bear, 1996). Multiple forms of metaplasticity have been demonstrated to exist in the CNS and many of these involve the same overlapping molecular machinery as Hebbian plasticity. Therefore, it has been difficult to disentangle and ascribe specific roles for metaplasticity and Hebbian synaptic potentiation in memory formation.

One form of metaplasticity observed in the hippocampus occurs through long-term depression of inhibitory synapses (I-

Received July 5, 2013; revised 0ct. 15, 2014; accepted 0ct. 28, 2014.

Author contributions: J.X. and A.C. designed research; J.X., M.D.A., T.N., S.K., Y.Z., and A.C. performed research; J.X., M.D.A., T.N., and A.C. analyzed data; J.X. and A.C. wrote the paper.

This work was supported with the National Institutes of Health-National Institute of Neurological Disorders and Stroke (Grant R01NS058894), the National Institutes of Health-National Institute of Mental Health (Grants R01MH099114), and the McKnight Foundation (to A.C.). J.X. was funded by the Training Program in General Motor Control Mechanisms and Disease (Grant 5T32NS041234) and the National Institutes of Health-National Institute of Mental Health (Grant K01 MH094464). We thank Geoffrey T. Swanson for comments on the manuscript. We also thank Craig Weiss and John M. Linardakis in the Behavioral Phenotyping Core at Northwestern University for their assistance.

The authors declare no competing financial interests.

Correspondence should be addressed to Anis Contractor, Department of Physiology, Northwestern University Feinberg School of Medicine, 303 E. Chicago Ave, Chicago, II 60611. E-mail: a-contractor@northwestern.edu.

DOI:10.1523/JNEUROSCI.2869-13.2014

Copyright $\odot 2014$ the authors $\quad 0270-6474 / 14 / 3416762-12 \$ 15.00 / 0$
LTD; Chevaleyre and Castillo, 2003). I-LTD in CA1 neurons facilitates the potentiation of excitatory synapses and thus primes Hebbian LTP through a heterosynaptic mechanism. I-LTD is mediated by endocannabinoids (eCBs), which are diffusible retrograde messengers released from the postsynaptic neuron after activation of group $1 \mathrm{mGluRs}$ (Chevaleyre and Castillo, 2004). Although this form of plasticity has been described in detail in vitro, it remains unknown how it contributes to learning and memory. Group I mGluRs are critical to the induction of I-LTD, but it is not clear whether one or both types, mGluR1 and mGluR5, play a role (Chevaleyre and Castillo, 2003). Both types are present in the hippocampus and are proposed to play complex roles in regulating neuronal excitability and synaptic plasticity, although there are conflicting reports implicating mGluR5 in NMDA receptor-dependent long term potentiation (NMDARLTP; Lu et al., 1997; Francesconi et al., 2004; Bortolotto et al., 2005; Neyman and Manahan-Vaughan, 2008). Therefore, it is possible that group 1 mGluRs contribute directly to Hebbian plasticity mechanisms as well as metaplasticity in the hippocampus, although there is no consensus on which receptor types contribute to which forms of plasticity.

Here, we made use of conditional knock-out mice to address the roles of mGluRs in hippocampal CA1 plasticity and hippocampaldependent learning. I-LTD was impaired in mGluR5 CA1-ko animals, as was priming-induced facilitation of theta burst LTP, whereas there was no deficit apparent in Hebbian plasticity, confirming that mGluR5 in CA1 neurons play a specific role in metaplasticity by regulating inhibition. CA1-ko mice had impairments in a task involving making an association of two stimuli across time. Enhancing metaplasticity by inhibiting eCB hydrolysis increased both the acquisition and retention of learning in the memory task, further underscoring the connection between metaplasticity 
mechanisms and temporal associative learning. In addition to its essential roles in generating spatial maps, the hippocampus is also required for temporal aspects of episodic memory (McEchron et al., 1998; Wallenstein et al., 1998; Huerta et al., 2000; Crestani et al., 2002; Quinn et al., 2002). Our results suggest that metaplasticity in the CA1 could be a viable substrate for temporal memory encoding.

\section{Materials and Methods}

Animals. Floxed mGluR5 mice (mGluR $5^{\text {loxP/loxP }}$ ) were generated as described previously by incorporating two loxP sites into intronic regions flanking the exon coding for the 7 transmembrane regions of the receptor (Xu et al., 2009). mGluR5 ${ }^{\text {loxP/loxP }}$ mice were intercrossed with transgenic mice expressing Cre recombinase under the control of CaMKII promoter (CaMKII-cre; Tsien et al., 1996a). These mice have mixed C57 bl/6 and $129 /$ svj genetic backgrounds. Behavioral and slice physiology experiments in which comparisons were made between $\mathrm{Cre}^{+}$and $\mathrm{Cre}^{-}$littermates were performed blind to the genotype of the animal and post hoc genotyping performed from tail biopsies. All electrophysiology was performed in mice at week 7 . For behavioral experiments, training was started in mice at week 7 and mice tested at points appropriate for the experiments. Wild-type C57BL/6 mice (Jackson Laboratory) were used for experiments involving effects of drug administration on fear-related behaviors (see Fig. 5A-F). All animals were group housed with $14 \mathrm{~h}$ light/10 h dark light/dark cycle. Food and water were provided ad libitum. Male mice were used for all behavioral experiments, whereas mice of either sex were used for electrophysiological recordings. All experiments were approved by the Institutional Animal Care and Use Committees at Northwestern University.

Chemicals. MPEP and AM251 were purchased from Tocris Bioscience. JZL184 and URB597 were purchased from Cayman Chemical. For electrophysiology experiments, chemicals were dissolved in solvent recommended by the manufacturer. For behavioral experiments, URB597 was dissolved in 1:9 DMSO:PBS at a concentration of $1 \mathrm{mg} / \mathrm{ml}$ for the stock solution. More consistent results were obtained when JZl184 was dissolved in DMSO $(10 \mathrm{mg} / \mathrm{ml}$ stock solution). To minimize the effects of DMSO on behaviors, $<1 / 1000$ DMSO of the mouse bodyweight was administered. The drug and vehicle were administrated to mice intraperitoneally in all experiments.

Slice preparation and electrophysiology. Animals of either sex were anesthetized and rapid cardiac perfusion was performed with ice-cold sucrose artificial CSF (ACSF) solution containing the following (in $\mathrm{mM}$ ): 85 $\mathrm{NaCl}, 2.5 \mathrm{KCl}, 1.25 \mathrm{NaH}_{2} \mathrm{PO}_{4}, 25 \mathrm{NaHCO}_{3}, 25$ glucose, 75 sucrose, 0.5 $\mathrm{CaCl}_{2}$, and $4 \mathrm{MgCl}_{2}$, equilibrated with $95 \% \mathrm{O}_{2}$ and $5 \% \mathrm{CO}_{2}$ before decapitation and removal of the brain. Transverse hippocampal slices were made from the ventral hippocampus and transferred to a holding chamber, initially at $26^{\circ} \mathrm{C}$, for $1 \mathrm{~h}$; during which time the slicing solution was exchanged for a normal ACSF containing the following (in $\mathrm{mM}$ ): 125 $\mathrm{NaCl}, 2.4 \mathrm{KCl}, 1.2 \mathrm{Na}_{2} \mathrm{PO}_{4}, 25 \mathrm{NaHCO}_{3}, 25$ glucose, $1 \mathrm{CaCl}_{2}$, and 2 $\mathrm{MgCl}_{2}$ and gradually allowed to return to room temperature. Individual slices were transferred to a recording chamber and visualized under DIC optics. For field recordings, electrodes were fabricated from borosilicate glass at a resistance of 3-5 M $\Omega$ and filled with regular ACSF. EPSPs were evoked using a bipolar tungsten electrode placed in the stratum radiatum to stimulate Schaffer collateral inputs to CA1. Data were collected and analyzed using pClamp 10 software (Axon Instruments). For voltageclamp experiments, to record IPSCs, electrodes were filled with an internal solution consisting of the following (in mM): $70 \mathrm{CsCH}_{3} \mathrm{SO}_{3}, 60 \mathrm{CsCl}$, $1 \mathrm{MgCl}_{2}, 0.2$ EGTA, 10 HEPES, 2 Mg-ATP $0.3 \mathrm{GTP}^{-\mathrm{Na}_{2}}, 10 \mathrm{Na}_{2}$ phosphocreatine,10 TEA, and 5 QX-314. Recorded cells were voltage clamped at $+10 \mathrm{mV}$ or at $-70 \mathrm{mV}$. For current-clamp recordings, electrodes were filled with the following (in $\mathrm{mM}$ ): $125 \mathrm{KMeSO}_{4}, 5 \mathrm{KCl}, 11$ HEPES, 0.02 EGTA, $5 \mathrm{NaCl}, 4 \mathrm{Mg}$-ATP, $0.3 \mathrm{Na}-\mathrm{GTP}, 1 \mathrm{MgCl}_{2}$, and 10 $\mathrm{Na}_{2}$-phosphocreatine.

Immunohistochemistry. For immunohistochemical analysis of mGluR5 expression in mGluR5 ${ }^{\text {loxP/loxP }}$;CaMKII-cre mice, sections were made from $\mathrm{Cre}^{-}$and $\mathrm{Cre}^{+}$at 8 weeks. Sections were stained using a polyclonal rabbit anti-mGluR5 antibody that recognizes 21 residues corresponding to the C-terminal of mGluR5 (06-451, 1:500 dilution; Millipore).

Western blot. The CA1 of the hippocampus, cortex, and striatum were microdissected after making $300-400 \mu \mathrm{m}$ sections. The tissue was homogenized with a glass pestle into ice-cold RIPA lysis buffer containing $50 \mathrm{~mm}$ Tris, $150 \mathrm{~mm} \mathrm{NaCl}, 5 \mathrm{~mm}$ EDTA, 0.5\% sodium deoxycholate, $0.1 \%$ SDS, and $1 \%$ Triton X-100, pH 7.4. RIPA buffer was supplemented with a protease inhibitor mixture ( 1 tablet/10 ml; Roche). Lysate was cleared by centrifugation in a microcentrifuge $(20 \mathrm{~min}$ at $12000 \mathrm{rpm}$ at $4^{\circ} \mathrm{C}$ ). The protein content was determined using the BCA assay (Pierce). Equivalent amounts of protein from each sample $(\sim 20 \mu \mathrm{g})$ was resolved via SDS-PAGE with $10 \%$ Tris- $\mathrm{HCl}$ acrylamide gels and blotted onto polyvinylidene fluoride membranes in a methanol/Tris-glycine buffer. Antibodies used were as follows: mGluR5 (1:4000; Millipore catalog \#AB5675); $\beta$-tubulin (1:10 000; Sigma-Aldrich, catalog \#T2200). $\beta$-tubulin signals were used as a loading control. Expression of mGluR5 in $\mathrm{Cre}^{+}$mice was normalized to the mean of the $\mathrm{Cre}^{-}$control.

Morris water maze. The Morris water maze (MWM) experiments were conducted as described previously with some modification (Xu et al., 2009). Experiments were conducted in a 120 -cm-diameter water tank. The water was made opaque with white, nontoxic Crayola washable paint and maintained at room temperature. An automated video tracking system was used to record the swim path, velocity, and time taken to reach the platform (latency) or the time spent in each zone. Mice were first trained to find the visible platform for 3 consecutive days ( 3 trials per day). A thin black plastic brick $(8 \times 13 \times 1.5 \mathrm{~cm})$ was placed above the transparent platform and a flag was installed $10-15 \mathrm{~cm}$ above the surface, allowing mice to visualize the location of the platform. Mice were released from the southwest (SW) quadrant for all trials. The platform was rotated from the northeast (NE) to northwest (NW) to southeast (SE) quadrant for each trial. After release, each mouse was allowed a maximum of $60 \mathrm{~s}$ to find the visible platform. Mice that failed to find the platform within $60 \mathrm{~s}$ were placed onto the platform. Mice were allowed to remain on the platform for $15 \mathrm{~s}$ after each trial. Hidden platform training was conducted $1 \mathrm{~d}$ after the completion of the visible platform training. Mice were trained for $7 \mathrm{~d}$ ( 3 trials per day) to find the submerged platform at a fixed position (center of NE quadrant) with the aid of distal cues in the testing room. The first probe trial was administered $24 \mathrm{~h}$ after the last trial of the hidden platform training. During the probe trial, the mouse was allowed to swim for $60 \mathrm{~s}$ without the platform in the tank. For reverse platform training, the hidden platform was moved from the NE quadrant to the center of the SW quadrant without changing the distal visual cues. Mice were trained to find this new platform location for $4 \mathrm{~d}$ ( 3 trials per day).

Fear conditioning. Two different tracking and monitoring systems have been used in our experiments. Fear conditioning experiments described in Figure 3 were performed using an automated video system (Med Associates). For the fear conditioning experiments described in Figure 5, we used the Freezeframe Video Tracking system (Actimetrics). Behavioral experimental procedures were essentially the same in the two sets of experiments using the two different tracking and monitoring systems.

Mice were handled daily for 1 week before testing. Chambers were cleaned with $70 \%$ ethanol between each set of mice. Auditory fear memory tests were conducted in a novel context. For delay fear conditioning, training on the first day lasted for $6 \mathrm{~min}$. Each mouse was subjected to training that consisted of $3 \mathrm{~min}$ of baseline monitoring, followed by 3 pairs of $20 \mathrm{~s}$ tone $(85 \mathrm{db}, 2900 \mathrm{~Hz})$ co-terminated with $1 \mathrm{~s}$ footshock $(0.7$ $\mathrm{mA}$ ) given at $1 \mathrm{~min}$ intervals. For trace fear conditioning, the tone and footshock were separated by a precise time interval (2-30 s). Design for the trace fear conditioning experiments were modified from previous studies (Huerta et al., 2000; Zhao et al., 2005). Briefly, the conditioned stimulus (CS) used was a $15 \mathrm{~s}$ tone $(85 \mathrm{db}, 2900 \mathrm{~Hz})$, and the unconditioned stimulus (US) was a $0.6 \mathrm{~mA}$ footshock for $0.5 \mathrm{~s}$. Mice were acclimated for $60 \mathrm{~s}$ before the presentation of CS-trace-US. Intertrial intervals (ITIs) were $240 \mathrm{~s}$. The number of ITIs varied in different experiments and is described in detail in the Results section. The memory test for trace fear conditioning was conducted $24 \mathrm{~h}$ after training. Mice were placed in a novel context and were presented with $415 \mathrm{~s}$ tones, each separated by 
$240 \mathrm{~s}$. The contextual fear memory test was conducted $48 \mathrm{~h}$ after training. Mice were reintroduced to the training context for $6 \mathrm{~min}$ without footshocks and tone presentation.

Data analysis. Statistical analyses were conducted with GraphPad Prism software. For the behavior experiments with multiple trials including fear conditioning training, extinction tests, and MWM tests, two-way repeated-measures ANOVA was conducted to assess the effects of both genotype and sessions/trials. Student's $t$ test was used to compare two means. For slice physiology experiments, differences between two means were assessed with $t$ tests. Differences among groups were assessed with one-way ANOVA. The Kolmogorov-Smirnov (K-S) test was used for comparison of cumulative distributions. Data are presented as mean \pm SEM. Differences were considered significant when $p<0.05$.

\section{Results}

mGluR5 is required for priming-

induced metaplasticity in the CA1

Previous studies have suggested that group $1 \mathrm{mGluRs}$ play a prominent role in the hippocampus as a metaplastic switch by controlling the modifiability of synapses (Chevaleyre and Castillo, 2004); however, the identity of the receptor types has not been clear, making it impossible to dissect the roles of metaplasticity in hippocampal function. To further investigate the molecular mechanisms and physiological functions of metaplasticity in hippocampus, we generated mice in which mGluR5 was ablated from the CA1 pyramidal neurons by crossing mGluR5 $5^{\text {loxP/loxP }}$ (Xu et al., 2009) mice with transgenic mice expressing Cre recombinase under the control of the regulatory region of CaMKII (CaMKII-cre; Tsien et al., 1996b). Consistent with previous studies using the CaMKII-cre transgenic line (Tsien et al., 1996a), Cre recombinase-mediated deletion of mGluR 5 was evident at 4-6 weeks (data not shown) and recombination and deletion of mGluR 5 was complete in CA1 neurons at 8 weeks (Fig. $1 A-C$ ). Previous reports have demonstrated that there is progressive Cre expression and recombination in cortical regions beyond the CA1 pyramidal neurons in older mice. Using Western blot analysis of tissue microdissected from cortex, we found that the relative expression of mGluR5 was not decreased in Cre ${ }^{+}$mice at 7 weeks after birth $(95.5 \pm 4.2 \%, n=4$; Fig. $1 B)$, whereas at 10 weeks, there was a significant reduction in the cortex $(64.1 \pm 5.3 \%, n=5$; Fig. $1 C)$. We did not find any difference in expression of mGluR5 in striatal tissue at either time point $\left(\mathrm{Cre}^{+}\right.$, week 7: $101.7 \pm 3.0 \%, n=$ 4; $\mathrm{Cre}^{+}$, week 10: $\left.93.3 \pm 6.4 \%, n=4\right)$. The reduction in mGluR5 protein in CA1 of the hippocampus was equivalent at 7 and 10 weeks, but was not completely eliminated as seen in the tissue samples from the constitutive knock-out mouse (-/-; Fig.
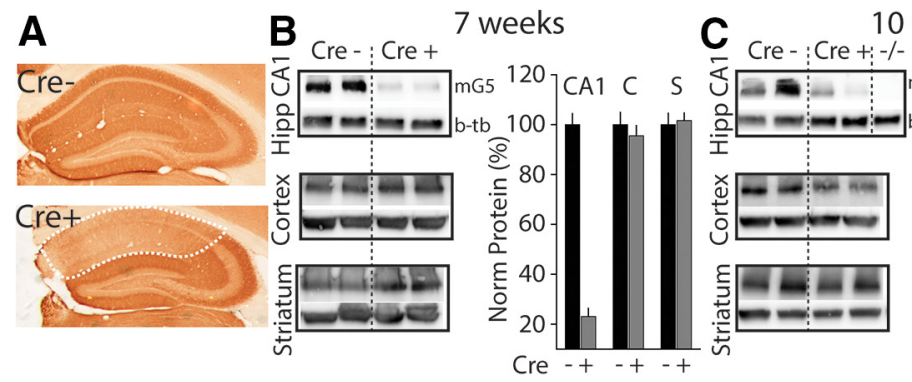

10 weeks
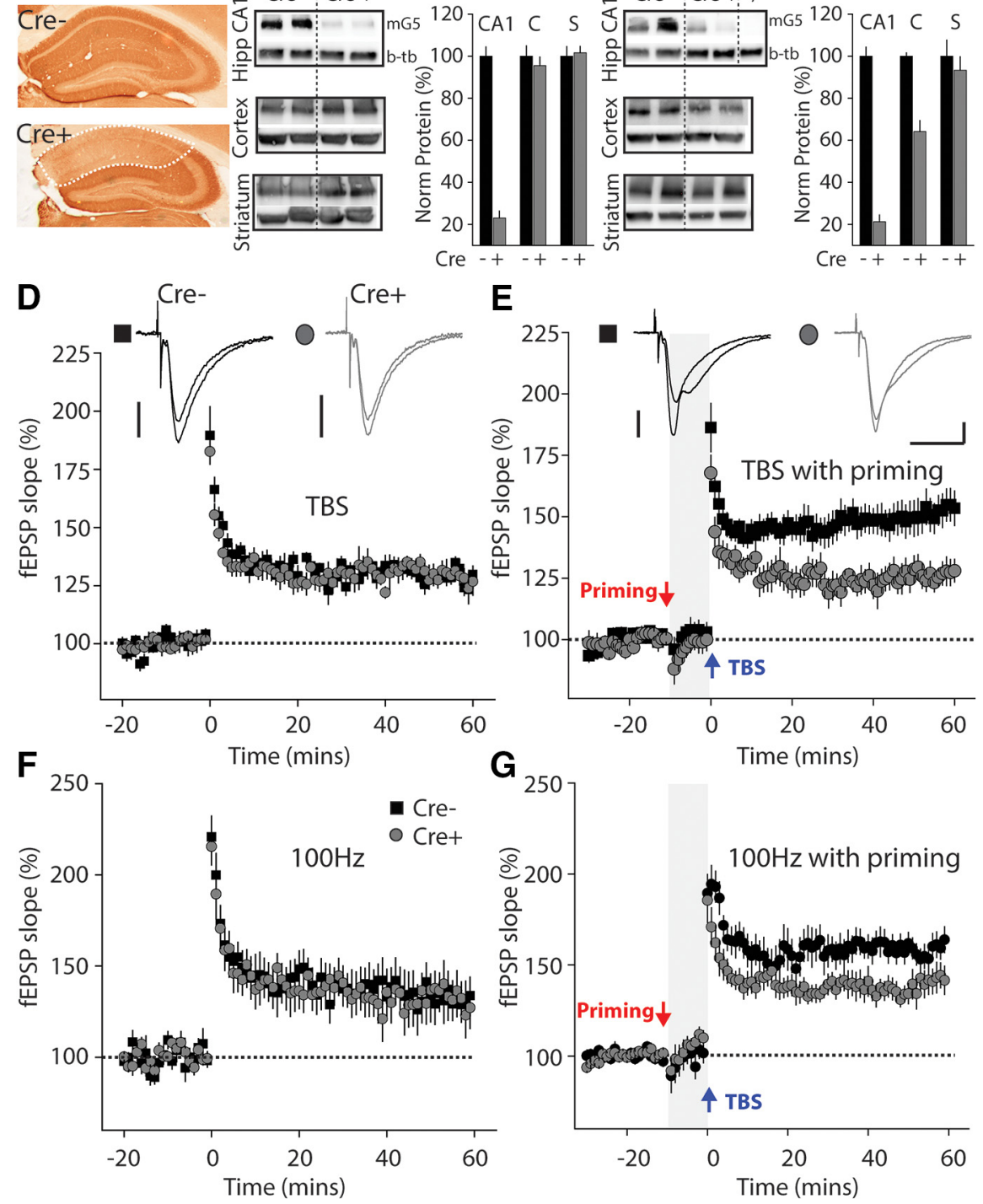

Figure 1. Restricted deletion of mGluR5 in CA1 neurons results in impairment of priming-induced facilitation of TBS-LTP. $\boldsymbol{A}$, Representative hippocampal sections from mGluR5 ${ }^{\text {loxP/loxP }}$; CaMKIICre ${ }^{-}\left(\mathrm{Cre}^{-}\right)$and $\mathrm{mGluR5}^{\text {loxP/loxP }}$;CaMKIICre ${ }^{+}\left(\mathrm{Cre}^{+}\right)$mice. Both sections are from mice at 8 weeks. $\boldsymbol{B}$, Western blot analysis of mGluR5 expression in CA1 hippocampus, cortex, and striatum of $\mathrm{Cre}^{-}$and $\mathrm{Cre}^{+}$mice at 7 weeks. mGluR5 protein was normalized to $\beta$-tubulin expression. $C$, Analysis of mGluR5 expression in 10-week-old mice from $\mathrm{Cre}^{-}$and $\mathrm{Cre}^{+}$mice. Additional control shows Western from constitutive mGluR5 ko tissue $(-/-. \boldsymbol{D}$, Time course of CA1 TBS-LTP in Cre ${ }^{-}$(black squares) and $\mathrm{Cre}^{+}$(gray circles). TBS-LTP was induced using a train of stimuli consisting of 5 stimuli at $50 \mathrm{~Hz}$ repeated 10 times at $5 \mathrm{~Hz}$. Above are representative fEPSPs before and after TBS-LTP induction from $\mathrm{Cre}^{-}$and $\mathrm{Cre}^{+}$mice. E, Priming-induced facilitation of TBS-LTP in slices from $\mathrm{Cre}^{-}$mice but not in slices from $\mathrm{Cre}^{+}$mice. The priming train consisted of 210 s episodes of $10 \mathrm{~Hz}$ stimulation separated by $20 \mathrm{~s}$. Above are representative fEPSPs before priming and $50-60 \mathrm{~min}$ after TBS stimulation. Calibration for $\boldsymbol{D}$ and $\boldsymbol{E}: 0.25 \mathrm{mV}, 50 \mathrm{~ms}$. $\boldsymbol{F}$, Time course of $100 \mathrm{~Hz}$ LTP experiments in $\mathrm{Cre}^{-}$(black squares) and $\mathrm{Cre}^{+}$(gray circles) mice. LTP was induced using a single $1 \mathrm{~s} 100 \mathrm{~Hz}$ train. Potentiation was measured between 50 and $60 \mathrm{~min}$ after induction. G, Time course of $100 \mathrm{~Hz}$ LTP with prior priming. LTP is larger after priming in $\mathrm{Cre}^{-}$mice than in $\mathrm{Cre}^{+}$mice.

$1 B, C)$. This likely reflects the expression of mGluR5 in interneurons (van Hooft et al., 2000) and astrocytes (Cai et al., $2000)$ in the CA1 region, which are not ablated by CaMKIICre expression. Because of the age-dependent pattern of knockout in the cortex, experiments in this study were initiated in mice at week 7 for all experiments, during which period mGluR5 deletion in CA1 pyramidal neurons is complete, whereas expression in cortical regions is mostly unaffected.

We first determined whether NMDA-mediated Hebbian LTP was affected by mGluR5 knock-out in CA1 pyramidal neurons. Using a theta-burst induction (TBS-LTP) stimulus, we found 

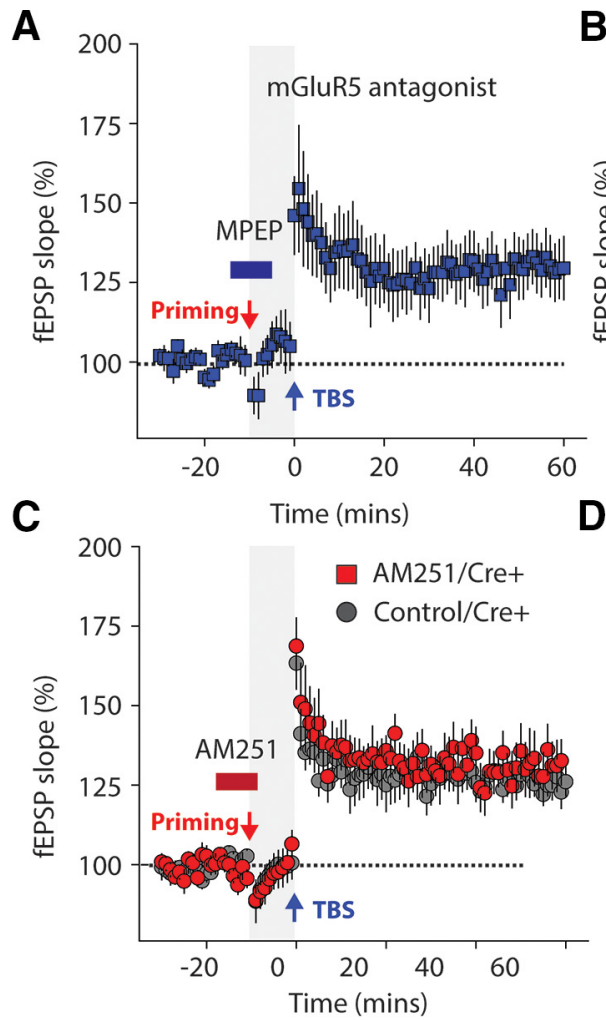

In slices from $\mathrm{Cre}^{-}$control animals, we saw a robust increase in TBS-induced plasticity $60 \mathrm{~min}$ after induction in primed slices (Cre ${ }^{-}$with priming: $150 \pm$ 7.0, $n=12$ slices from 10 mice; Fig. $1 E$ ) compared with recordings from $\mathrm{Cre}^{-}$animals with no priming $(130 \pm 4.9 n=6$, $p<0.05$; Fig. $1 D)$. The priming train itself had no long-lasting effect on the fEPSP, which was unchanged from baseline 10 min after priming and before delivery of TBS (Fig. 1E, shaded area). In slices from CA1-ko animals, synaptic priming failed to enhance TBS plasticity (Cre ${ }^{+}$with priming: $126 \pm 3.6 \%, n=11$ slices from 9 mice; Fig. 1E) compared with $\mathrm{Cre}^{+}$without priming $(130 \pm 4.6, n=6, p>0.05$; Fig. $1 D)$. Overall, there was a significant difference in priming-facilitated TBS-LTP between recordings from CA1-ko and control littermates $(p<0.01$; Fig. $1 E)$. In a separate group of experiments, we also found that priming facilitated $100 \mathrm{~Hz}$ tetanus LTP although to a lesser degree than TBS LTP, but in these experiments as well, LTP after priming was significantly larger in control mice compared with CA1-ko mice $\left(\mathrm{Cre}^{-}: 160 \pm 5.2 \%, n=10\right.$ slices from 7 mice; Cre $^{+}: 140 \pm 7.1 \%, n=9$ slices from 7 mice; $p<0.05$; Fig. $1 G)$. Therefore, mGluR5 signaling in CA1 pyramidal neurons is required in metaplastic priming of synapses for subsequent facilitation of Hebbian potentiation.

Previous studies have demonstrated that the mechanisms of priming-induced potentiation involve an mGluR-mediated

that there was no difference in the amount of potentiation measured up to $1 \mathrm{~h}$ after LTP induction in recordings from CA1-ko and control littermates $\left(\mathrm{Cre}^{+}: 130 \pm 4.6, n=6\right.$ from 6 mice; Cre $^{-}: 130 \pm 4.9, n=5$ from 5 mice $p>0.05$; Fig. $\left.1 D\right)$. Similarly, no differences in Hebbian plasticity were observed in CA1-ko mice when tetanic induction protocols were used. There was no difference in the early phase of LTP induced by a standard single $1 \mathrm{~s}$ train of stimulation at $100 \mathrm{~Hz}\left(\mathrm{Cre}^{+}: 133 \pm 11.3 \%, n=9\right.$ slices from 8 mice; Cre $^{-}: 132 \pm 9.68 \%, n=9$ slices from 6 mice; $p>$ 0.05 ; Fig. $1 F$ ) or a more robust induction paradigm (4 $1 \mathrm{~s}$ trains at $100 \mathrm{~Hz}$ separated by an intertrain interval of $10 \mathrm{~s}$; Cre $^{+}: 161 \pm$ $10.2 \%, n=15$ slices from 6 mice; Cre ${ }^{-} 172 \pm 12.0 \%, n=15$ slices from 5 mice; $p>0.05)$. In addition, the magnitude of late phase LTP (L-LTP) was not different in CA1-ko animals $\left(\mathrm{Cre}^{+}\right.$: $143 \pm 6.6 \%, n=10$ slices from 10 mice; $\mathrm{Cre}^{-}: 150 \pm 10.7 \%, n=$ 10 slices from 10 mice, $p>0.05$ ). LTP was induced by $4,1 \mathrm{~s}$ trains of stimulation at $100 \mathrm{~Hz}$, measured at 170-180 min after LTP induction. This supports previous findings that have demonstrated little or no direct role of mGluR5 in Hebbian LTP in the hippocampus (Bortolotto et al., 2005; Bortolotto et al., 2008). In further experiments, we tested whether mGluR5 in CA1 neurons may be required for gating metaplasticity. A theta burst stimulation (TBS) protocol was again used that induces subsaturating LTP; however, in these experiments, a priming train $(2,10 \mathrm{~s}$ episodes of $10 \mathrm{~Hz}$ stimulation separated by $20 \mathrm{~s}$ ) was applied 10 min before theta burst delivery (Chevaleyre and Castillo, 2004). mobilization of eCBs and LTD of inhibitory synapses (Chevaleyre and Castillo, 2004). We confirmed that priming-induced potentiation was blocked by a group 1 antagonist MPEP ( $15 \mu \mathrm{M}$; $130 \pm 7.8 \%, n=8$ slices from 6 mice; $p>0.05$ compared with nonprimed TBS; Fig. 2A) and also by the cannabinoid receptor type $1(\mathrm{CB} 1 \mathrm{R})$ antagonist AM251 $(2 \mu \mathrm{M} ; 123 \pm 5.2 \%$; $n=6$ slices from 4 mice, $p>0.05$; Fig. $2 B$ ) in control mice. In contrast, there was no effect of AM251 in similar experiments in CA1-ko mice (control $126 \pm 3.6 \%, n=11$ from 9 mice; AM251 $132 \pm 7.3 \%$, $n=10$ from 7 mice, $p>0.05$; Fig. $2 C$ ). Therefore, it is clear that priming involves the activation of mGluR5 and subsequent signaling through CB1 receptors. Moreover, these data indicates that blocking only mGluR5 during the priming period is sufficient to prevent facilitation of TBS-induced LTP.

\section{CA1-ko mice have normal spatial memory but impairments in memory requiring temporal processing}

We previously demonstrated that animals with constitutively deleted mGluR5 ( $\mathrm{mGluR5}^{-/-}$) demonstrate slower learning in the standard MWM task, although their spatial memory was intact (Xu et al., 2009). This test of spatial learning and memory relies in part on the hippocampus and there is a strong link between Hebbian plasticity and spatial memory (Tsien et al., 1996a; Shapiro and Eichenbaum, 1999). Given the putative involvement of mGluR5 in CA1 synapse plasticity, we tested whether CA1-ko mice display deficits in spatial learning. Mice $\left(\mathrm{Cre}^{+}: n=25\right.$; 
A

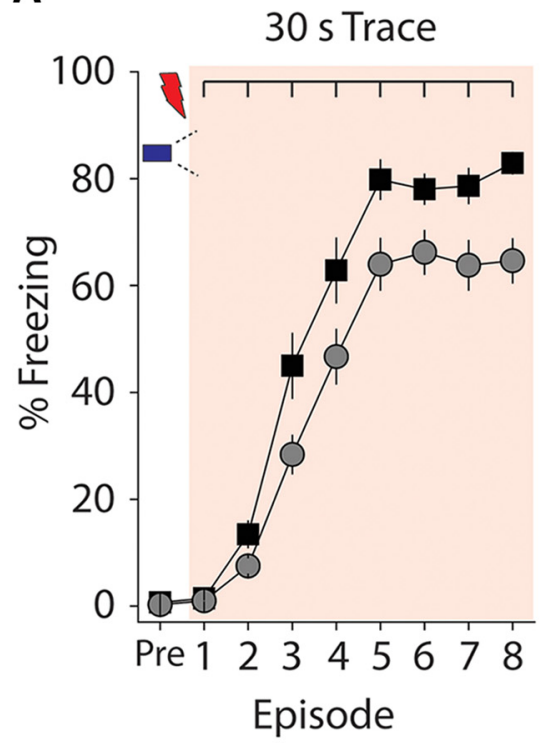

B

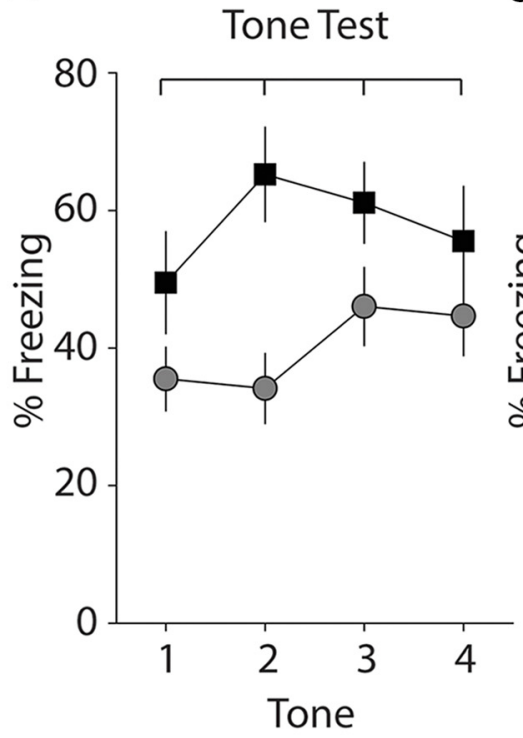

C

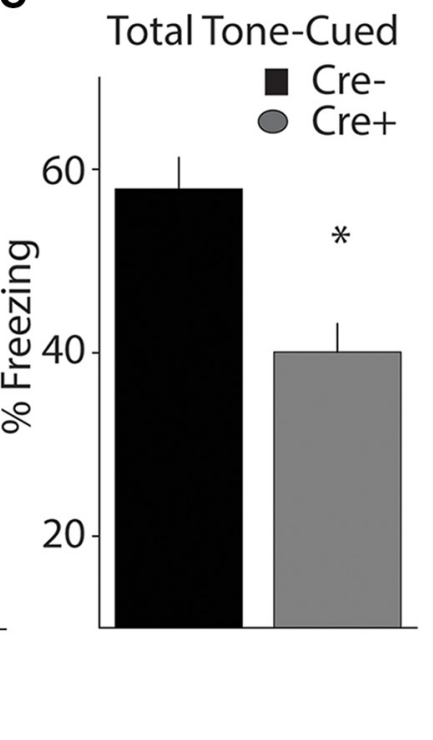

\section{Delay Conditioning E Tone Test 1}

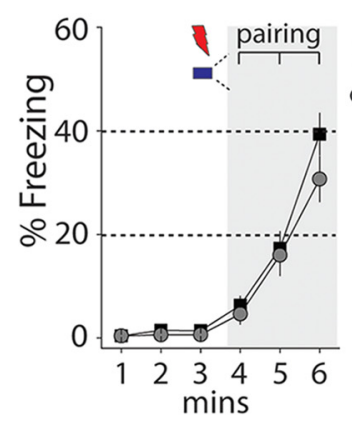

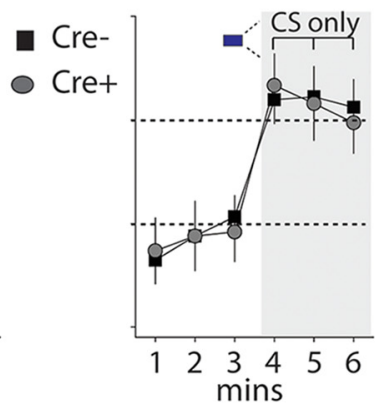

F Tone Test 2

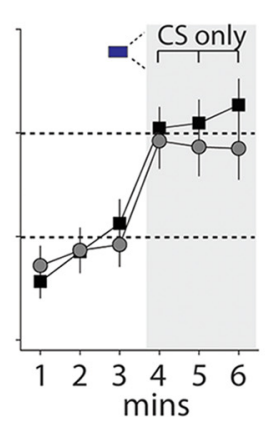

G

Context

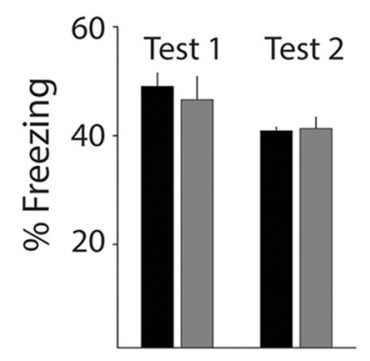

Figure 3. CA1-ko animals are impaired in forming strong temporally separated associations. $A$, Trace fear conditioning of Cre ${ }^{-}$(black squares) and Cre ${ }^{+}$(gray circles) mice. Mice were trained with eight CS (tone)-US (footshock) pairings. Inter-trial intervals (ITls) were $240 \mathrm{~s}$. CS and US were separated by a 30 s trace period. The amount of freezing to the $15 \mathrm{~s}$ tone and $45 \mathrm{~s}$ afterward is quantified for each pairing episode. $\boldsymbol{B}$, Tone test performed on subsequent day. Animals were returned to a new context and were presented with 4 tones of $15 \mathrm{~s}$ at $240 \mathrm{~s}$ interval. Each point represents the total freezing during each of the $15 \mathrm{~s}$ tone presentations and during $45 \mathrm{~s}$ after the tone. $\mathbf{C}$, Quantification of total freezing during four successive tones ( $p=0.01, t$ test). $\boldsymbol{D}-\mathbf{G}$, Delay fear conditioning of CA1-ko mice and control mice using coterminating CS (tone) and US (footshock) pairing. $\boldsymbol{E}, \boldsymbol{F}$, Tone test performed on subsequent days and 2 weeks later demonstrated that $C$ re and $\mathrm{Cre}^{+}$animals displayed equivalent tone-cued freezing. G, Quantification of freezing to the context conducted $1 \mathrm{~d}$ (test1) and $14 \mathrm{~d}$ (test2) after training.

$\left.\mathrm{Cre}^{-}: n=24\right)$ were tested in the MWM and we found no difference between the groups in performance during the $3 \mathrm{~d}$ of visible platform training ( 3 trials per day), $\mathrm{V} 1$ to $\mathrm{V} 3\left(F_{(1,47)}=0.01, p>\right.$ 0.05 , two-way ANOVA), during the hidden platform test $\mathrm{H} 1$ to H7 $\left(F_{(1,47)}=0.13, p>0.05\right.$, two-way ANOVA, or during the probe test conducted $24 \mathrm{~h}$ after hidden platform training $(p>$ $0.05, t$ test). Global mGluR5 ${ }^{-1-}$ mice have a robust impairment in performance in the reversal of the MWM test, suggesting that mGluR5 is critical for inhibitory learning (Xu et al., 2009); however, analysis of escape latencies and path lengths demonstrated that there was no difference in performance in CA1-ko mice $\left(F_{(1,47)}=2.14, p>0.05\right.$ for escape latencies; $F_{(1,47)}=1.48, p>$ 0.05 for the path lengths, two-way ANOVA). We conclude that CA1 mGluR5 is not essential for spatial learning or for reversal learning in the MWM.

Hippocampal-dependent episodic memory has both a spatial and temporal component (Wallenstein et al., 1998; Rolls and Kesner, 2006). Lesions of the CA1, but not the CA3, disrupt memory of sequential events that are separated over time (Kesner et al., 2005; Farovik et al., 2010) and CA1 synaptic plasticity has been linked to temporal associative learning (Huerta et al., 2000), suggesting that the CA1 region is critical for the encoding of temporal aspects of episodic memory. We tested mGluR5 CA1-ko mice in a task in which they are able to acquire and remember temporal associations using a fear conditioning paradigm with a CS-US pairing with a temporal separation of $30 \mathrm{~s}$ (30 s trace). We trained animals using a robust training paradigm with eight CS-trace-US pairings on the first day (Huerta et al., 2000; Zhao et al., 2005). CA1-ko mice demonstrated significant problems acquiring trace fear conditioning $\left(\mathrm{Cre}^{+}, n=35\right.$; $\mathrm{Cre}^{-}$, $n=23, F_{(1,56)}=9.33, p=0.003$, two-way ANOVA; Fig. $\left.3 A\right)$. Moreover, when animals were returned to a different context on a subsequent test day, mGluR5 CA1-ko animals froze significantly less to tone presentations, suggesting that they did not adequately associate the tone with the footshocks $\left(F_{(1,56)}=7.12\right.$, $p=0.01$; Fig. $3 B$ ). The total time that CA1-ko animals froze during 4 successive tones was significantly reduced $\left(\mathrm{Cre}^{+}: 40.1 \pm\right.$ $3.1 \%$; $^{-}{ }^{-}: 57.8 \pm 3.4 \% ; p=0.01, t$ test; Fig. $3 C$ ). This impairment was not due to a more general deficit in associative learning because CA1-ko mice did not have impairment in associating a CS with a co-terminating US (delay conditioning; Fig. 3D-G). Moreover, when shorter interval temporal separations were in- 

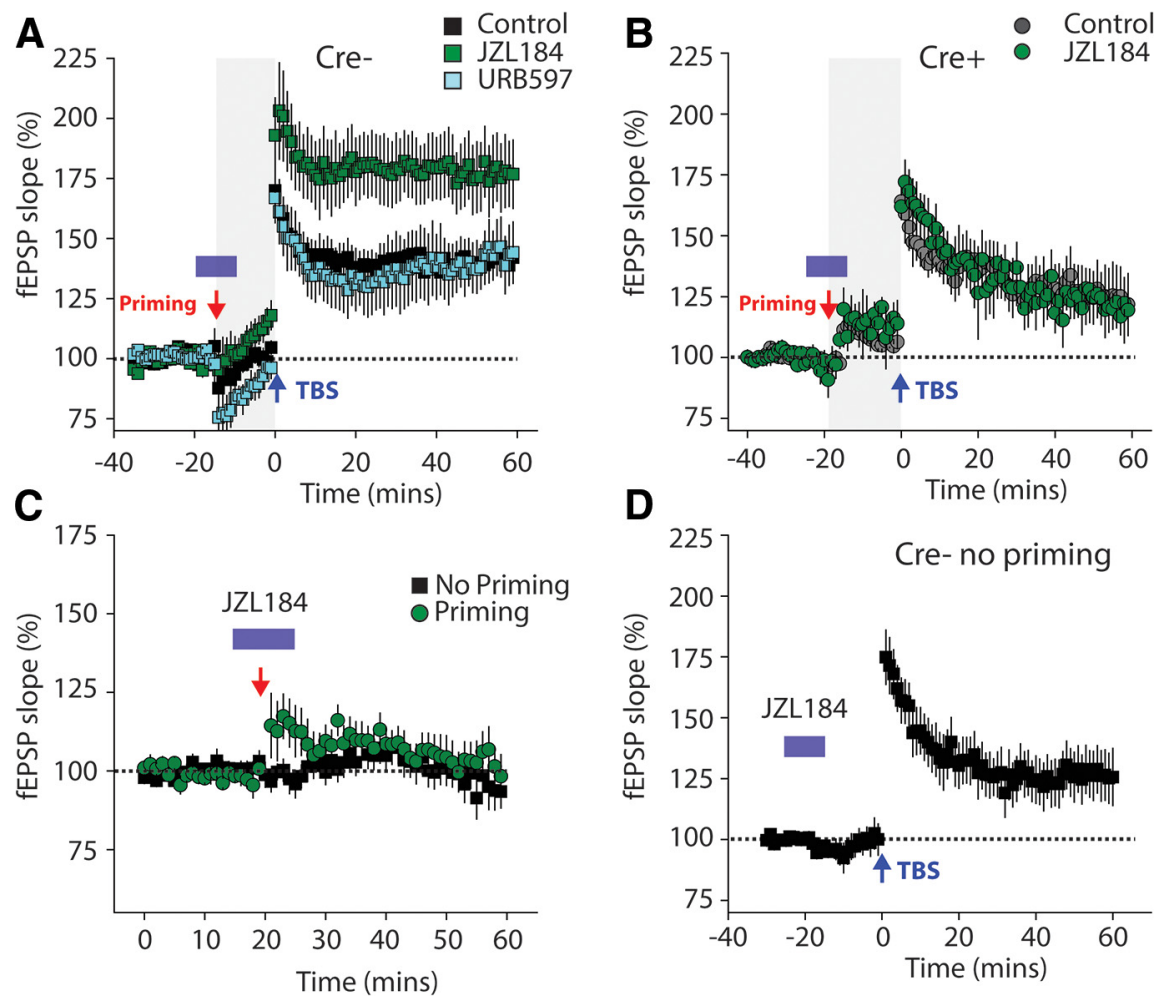

Figure 4. Blocking endocannabinoid hydrolysis enhances priming-induced facilitation of TBS-LTP. A, Primed TBS-LTP in Cremice (control, black squares) or in the presence the specific MAGL inhibitor JZL184 (green squares) or the selective inhibitor of FAAH, URB597 (cyan squares). Further potentiation of TBS-LTP is observed only after MAGL inhibition, demonstrating that 2-AG is mobilized by the priming train (single $10 \mathrm{~s}$ train at $10 \mathrm{~Hz}$ ). $\boldsymbol{B}, \mathrm{JZL} 184$ administration during priming has no effect on subsequent TBS-LTP in Cre ${ }^{+}$(CA1-ko) mice. C, JZL184 has little effect on basal fEPSPs either after priming or in slices without priming. $\boldsymbol{D}$, JZL184 administration without priming has no effect on the magnitude of subsequent TBS-LTP.

troduced between the CS and US ( 2 or $5 \mathrm{~s}$ ), knock-out animals acquired and remembered the associations comparably to control animals ( 5 s trace interval: $F_{(1,45)}=1.14, p>0.05$, two-way ANOVA; $2 \mathrm{~s}$ trace interval: $F_{(1,37)}=0.15, p>0.05$, two-way ANOVA). Therefore, CA1-ko of mGluR5 specifically disrupts associative learning when temporal processing of the stimuli association is required.

\section{Mechanisms of metaplasticity in the CA1 region of the hippocampus}

Our analysis has thus far demonstrated that ablation of mGluR5 in CA1 pyramidal neurons eliminates priming-induced metaplasticity and causes deficits in the acquisition of associations when a temporal component is introduced into the associative task. To establish a more explicit link between metaplasticity and temporal associative memory, we examined the mechanisms of this plasticity in more detail in the slice as a first step to determine whether the same signaling pathways are required for metaplasticity and learning. Because LTP priming involves eCB mobilization, we tested whether increasing eCBs pharmacologically would enhance the effect of priming on the amplitude of LTP. Of the two major eCB species in the brain, 2-arachidonoylglycerol (2AG) likely plays a major role in plasticity in the hippocampus (Chevaleyre and Castillo, 2003; Tanimura et al., 2010). To confirm the involvement of 2-AG, we performed priming TBS experiments in the presence of inhibitors of hydrolysis of 2-AG or $\mathrm{N}$-arachidonylethanolamine (AEA). To avoid possible saturation, we reduced the strength of priming by adopting a single $10 \mathrm{~s}$ train at $10 \mathrm{~Hz}$ in place of two trains. Fifteen minutes after prim- ing, one train of TBS stimulation was delivered to induce LTP. Application of JZL184 $(2 \mu \mathrm{M})$, the selective inhibitor of monoacylglycerol lipase (MAGL), the enzyme that degrades 2-AG (Long et al., 2009), caused a small enhancement of the fEPSP during the control period after the priming train (Fig. $4 A$, shaded area) and TBS-induced LTP after priming was significantly larger in amplitude (control: $140 \pm 7.1 \%, n=12$ slices from 8 mice; JZL184: $177 \pm 14.3 \% n=11$ slices from 6 mice, $p<0.05$; Fig. $4 A$ ). In contrast, application of URB597 $(2 \mu \mathrm{M})$, an inhibitor of fatty acid amide hydrolase (FAAH), the degradative enzyme of AEA (Mor et al., 2004), caused a significant depression of the fEPSP immediately after priming, which recovered over the $15 \mathrm{~min}$ postpriming interval (Fig. $4 A$, shaded area). Subsequent TBS produced LTP that was not different from control recordings (URB597: $142 \pm 10.1 \% n=8$ slices from 5 animals, $p>0.05$ vs control). In slices from CA1-ko mice, application of JZL184 during the priming had no additional enhancing effect on subsequent TBS LTP (Fig. 4B; Cre $^{+}$, control: $126 \pm 10.5 \%, n=$ 7 slices from 4 mice; Cre $^{+}$, JZL184: $119 \pm$ $5.6 \%, n=7$ slices from 4 mice). To determine whether the effects of JZL184 are specific to priming, in separate experiments, we tested the effect of JZL184 on basal transmission. A 10 min application of JZL184 had no effect on fEPSP stimulated at low frequencies (no priming; Fig. $4 C ; n=11$ slices from 5 mice). When a priming stimulus was given during JZL184 application, we saw a small and transient elevation of the fEPSP for several minutes after priming, which returned to baseline levels after $20 \mathrm{~min}$ (priming; Fig. 4C; $n=12$ slices from 5 mice). In addition, if JZL184 was applied during the baseline period without priming and TBS-LTP was induced $15 \mathrm{~min}$ later (after washout of JZL184), the magnitude of LTP was not enhanced further (Cre ${ }^{-}$, no priming, JZL184: $126.7 \pm 10.0 \%, n=9$ slices from 5 mice). These data suggest that $2-\mathrm{AG}$ is released by mGluR5 activation during the priming train and plays a significant role in enhancing subsequent LTP of excitatory synapses.

\section{Enhancing 2-AG signaling facilitates temporal associative learning}

Our findings that CA1-ko of mGluR5 specifically impairs endocannabinoid-mediated heterosynaptic metaplasticity and temporal associative learning provided the initial evidence that these forms of plasticity and learning may be connected. To further define the veracity of this link, we determined how the MAGL inhibitor JZL184, which enhanced metaplasticity in the slice, affected trace fear conditioning in vivo. In prior experiments, we had observed that freezing behavior starts to plateau after the third or fourth CS-trace-US pairing (Fig. 3A) and in these experiments to avoid overtraining, we used a conditioning protocol with fewer CS-trace-US pairings. With three pairings of CS-trace-US, we found that the drug group (JZL184, $5 \mathrm{mg} / \mathrm{kg} n=$ 8) displayed significantly elevated freezing during acquisition on 
A

day 1 - Acquisition JZL184

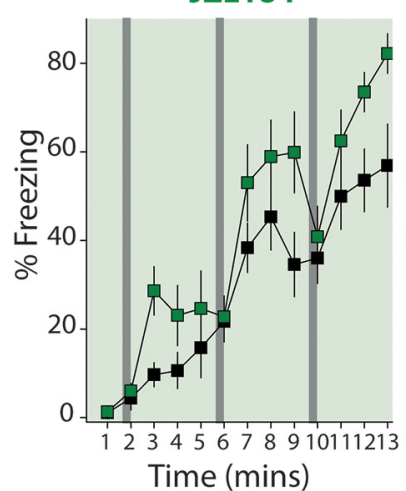

Time (mins)

D
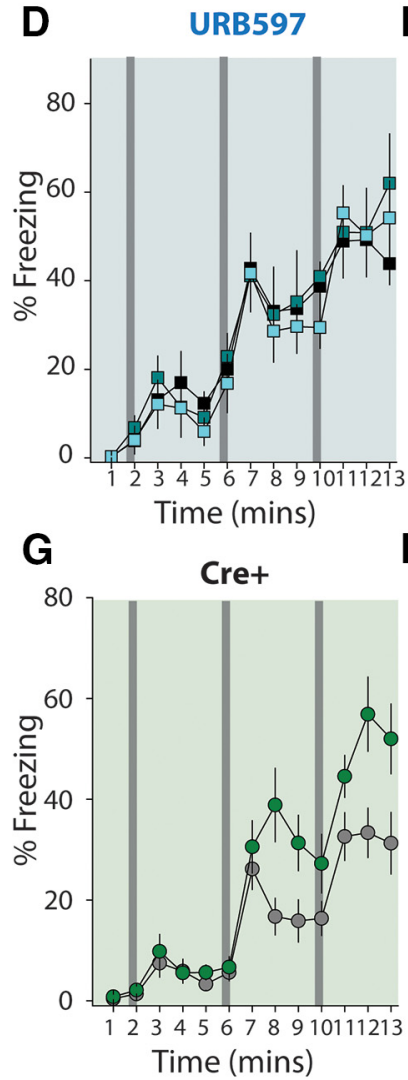

B

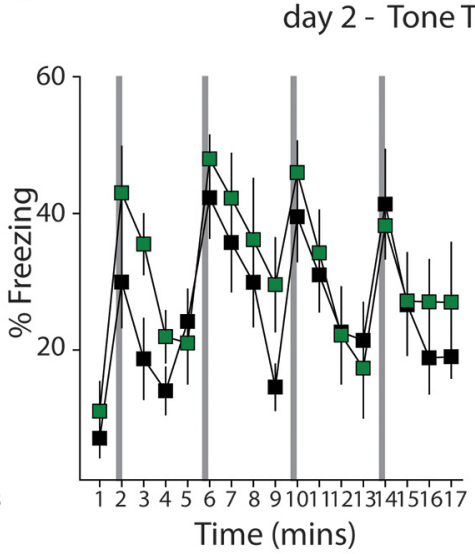

E

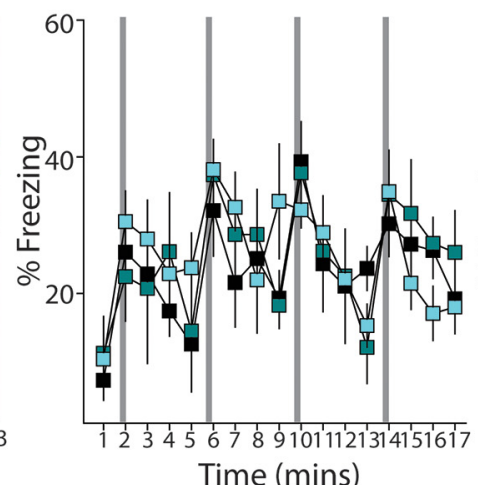

H

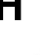

\section{E}

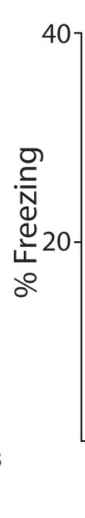

day 2 - Tone Test

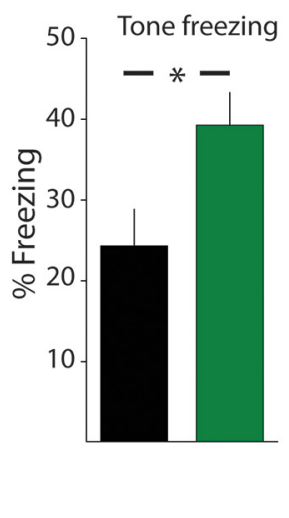

C

day 3- Context

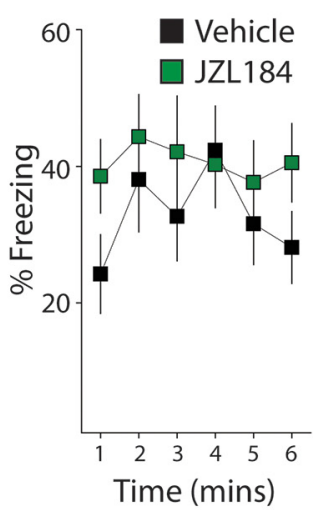

F

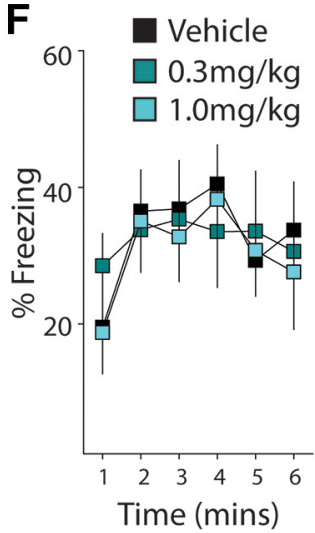

I

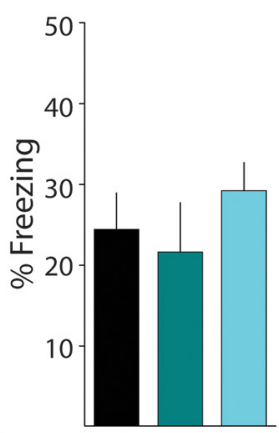

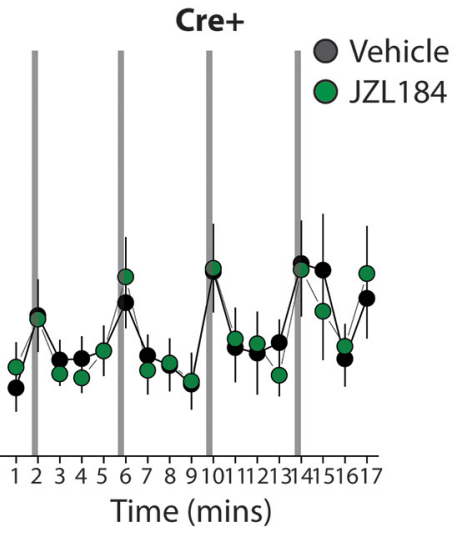

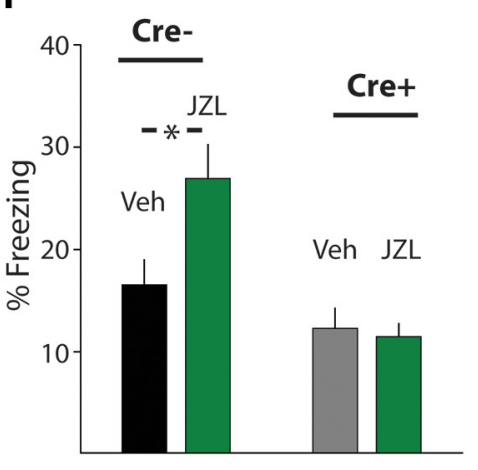

Figure 5. Inhibition of 2-AG hydrolysis enhances learning in a temporal associative memory task. A, Time course of trace conditioning. On day 1, vehicle (black squares) or JZL184 (5 mg/kg; green squares) was administered (intraperiteonally) to animals. Mice were returned to their home cage for $2 \mathrm{~h}$ before trace conditioning that consisted of 3 pairs of foot shocks ( $0.6 \mathrm{~mA}, 0.5 \mathrm{~s}$ ) and tones $(15 \mathrm{~s}, 85 \mathrm{db}, 2900 \mathrm{hz}$ ) presented every $4 \mathrm{~min}$. The JZL184-injected group displayed elevated freezing immediately following tones (gray bars). Freezing was averaged over 1 min during and after the tone. $\boldsymbol{B}$, Day 2 animals underwent the tone test (no shocks). Gray bars represent tone presentation. $\boldsymbol{B}$, Right, Average freezing during the first 2 min of the first episode of tone presentation. Animals that had previously been administered JZL184 during training demonstrated elevated tone freezing $(p<0.05 ; \boldsymbol{C})$. On day 3 , animals underwent the context test. Freezing was monitored in the original context over $6 \mathrm{~min}$. No difference was observed between the drug and vehicle group. D, Time course of trace fear conditioning in animals administered $0.3 \mathrm{mg} / \mathrm{kg}$ (cyan) or $1.0 \mathrm{mg} / \mathrm{kg}$ (light blue) URB579 and vehicle (black). No difference was observed in freezing between any of the groups either during training or tone test on day 2 ( $\boldsymbol{E}$, right panel is the average freezing during the first 2 min of the first episode) or context test on day $3(\boldsymbol{F})$. $\boldsymbol{G}$, Freezing is enhanced in $\mathrm{Cre}^{+}$mice administered JZL184 during acquisition. $\boldsymbol{H}$, In the subsequent tone test, there is no difference in tone freezing in vehicle or drug-treated $\mathrm{Cre}^{+}$mice. $\boldsymbol{I}$, Freezing during the tone test (after first tone) in $\mathrm{Cre}^{-}$and $\mathrm{Cre}^{+}$mice. JZL184-treated $\mathrm{Cre}^{-}$mice demonstrated enhanced freezing compared with the vehicle $\mathrm{Cre}^{-}$group. In $\mathrm{Cre}^{+}$mice, the JZL184-treated group did not have altered freezing during the tone test.

day $1\left(n=9\right.$; two-way ANOVA, $F_{(1,15)}=3.81, p=0.07$ for the effects of JZL184; $F_{(12,180)}=1.86, p=0.04$, for treatment $\times$ time interaction,; Fig. 5A). On the second day, animals were placed into a novel context and we monitored tone freezing. Four $15 \mathrm{~s}$ tones were presented without foot shock. Before the first tone, there was no difference in freezing between the two cohorts. Upon presentation of the first tone, both groups demonstrated freezing during and also after the tone (Fig. 5B); however, animals that had been conditioned with JZL184 administration demonstrated elevated freezing during the first episode (two-way ANOVA, $\left.F_{(1,15)}=4.82, p<0.05\right)$. When we averaged freezing during the first $2 \mathrm{~min}$ of the first episode, it was evident that the JZL184 group had higher freezing than the vehicle group $(p<$ $0.05, t$ test, Fig. $5 B$, right). During a further three episodes of tone 

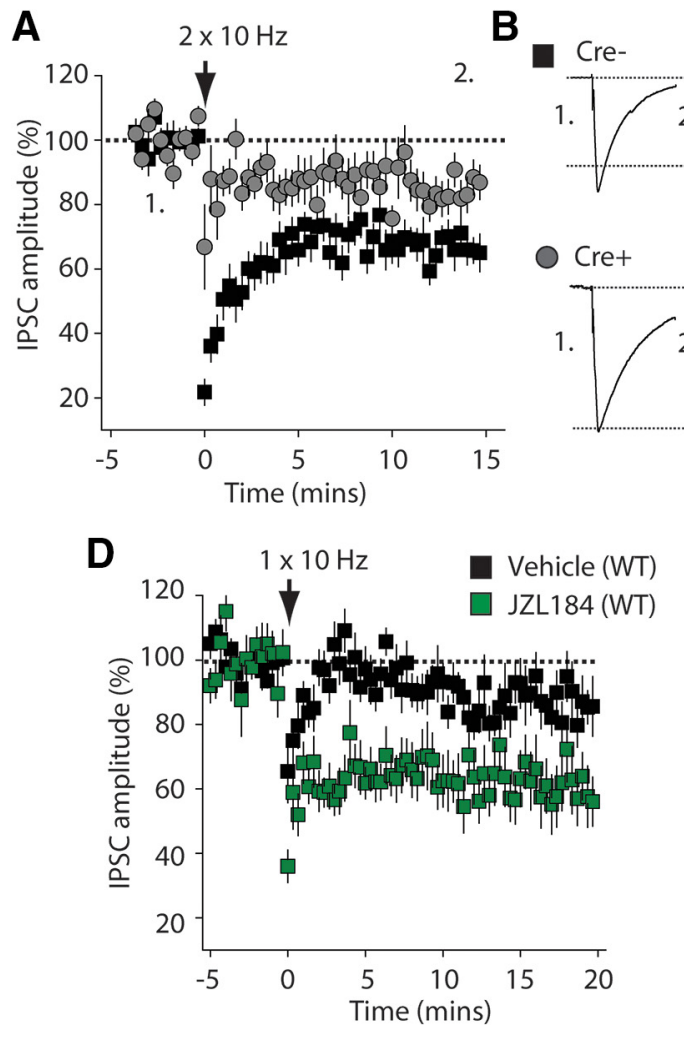

E

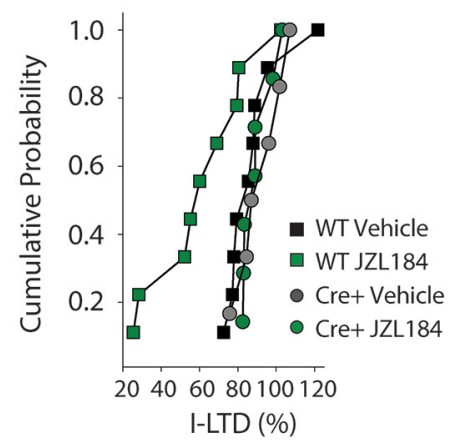

Figure 6. Priming train induces I-LTD. A, Time course of I-LTD in Cre ${ }^{-}$(black squares) and $\mathrm{Cre}^{+}$(gray circles) slices. I-LTD was induced by $210 \mathrm{~s}$ trains of $10 \mathrm{~Hz}$ stimulation separated by $20 \mathrm{~S}$. B, Representative IPSC traces for one experiment in $\mathrm{Cre}^{-}$and Cre ${ }^{+}$ mice. Calibration: 100 pA, 50 ms. C, Cumulative probability distribution for all I-LTD experiments. $D$, The amplitude of I-LTD induced by weak stimulation ( $1 \mathrm{train}$ of $10 \mathrm{~s}$ at $10 \mathrm{~Hz}$ stimulation) is enhanced in the presence of JZL184. Baseline was renormalized after JZl184 application, which by itself caused a small decline in the amplitude of basal IPSC, suggesting a tonic effect of 2-AG (Hashimotodani et al., 2007). $\boldsymbol{E}$, Cumulative probability distribution for all I-LTD experiments. Robust I-LTD was observed in slices from WT mice in the presence of JZL184. However, in slices from $\mathrm{Cre}^{+}$mice, little I-LTD was induced by the weak stimulation and this was not enhanced by bath application of JZL184.

presentation, there was no difference in freezing between the two groups (Fig. 5B). In addition, there was no difference between the groups in contextual fear memory tested on a subsequent day (vehicle group: $32.8 \pm 4.80 \%$; JZl184 group: $40.57 \pm 5.31 \%$, for averaged freezing over 6 min; $t$ test, $p>0.05$; Fig. $5 C$ ), demonstrating that JZL184 was selective for enhancement for tone association in the trace task.

Because our experiments in the hippocampal slice had indicated that inhibiting the degradation of 2-AG, but not AEA, enhanced metaplasticity, we next tested the effect of inhibiting FAAH with URB597 on trace conditioning. The doses of URB597 were chosen based on previous studies demonstrating that intraperitoneal administration can effectively inhibit FAAH activity in brain (Kathuria et al., 2003). Using two concentrations of URB597 (0.3 $\mathrm{mg} / \mathrm{kg}, n=6$, or $1.0 \mathrm{mg} / \mathrm{kg}, n=6$ ), we found no effect of FAAH inhibition on the acquisition of trace conditioning (two-way ANOVA, $F_{(2,15)}=0.16, p>0.05$, vehicle group $n=6$; Fig. $5 D$ ) or subsequent tone freezing on day 2 (two-way ANOVA, $F_{(2,15)}=$ $0.07, p>0.05 ;$ Fig. $5 E$ ). Finally, there was no difference among the 3 groups in contextual fear memory when animals were tested on day 3 (vehicle group: $32.7 \pm 2.9 \%$; URB597, $0.3 \mathrm{mg} / \mathrm{kg}$ group: $32.6 \pm$ 5.7\%; URB597, $1.0 \mathrm{mg} / \mathrm{kg}$ group: $30.5 \pm 5.5 \%$ average during 6 min; one-way ANOVA, $F_{(2,15)}=0.063, p>0.05$; Fig. $\left.5 F\right)$.

To determine how JZL184 affects associative learning when mGluR5 is ablated in the CA1, we repeated experiments in Cre ${ }^{+}$ and $\mathrm{Cre}^{-}$mice. There was no significant difference in freezing between the genotypes (two-way repeated-measures ANOVA,
$\left.F_{(1,26)}=1.45, p=0.23\right)$ and JZL184 enhanced freezing in both groups (for Cre ${ }^{-}$ mice, two-way repeated-measures ANOVA $F_{(1,22)}=6.28, p<0.05$, vehicle group, $n=12$, and JZL184 group, $n=12$; for $\mathrm{Cre}^{+}$mice, two-way repeatedmeasures ANOVA $F_{(1,26)}=5.013, p<$ 0.05 , vehicle group, $n=16$, and JZL184 group, $n=12$; see Fig. $5 G$ for $\mathrm{Cre}^{+}$ group). Despite the fact that freezing was also enhanced by JZL184 in the CA1-ko groups during fear acquisition, on day two during the tone test, there was no difference in freezing between the vehicleand drug-treated CA1-ko animals (Fig. $5 H, I)$, whereas the JZL184-administered $\mathrm{Cre}^{-}$group demonstrated significantly enhanced freezing, as expected (Fig. 5I). Together, these data demonstrate that selective inhibition of 2-AG hydrolysis enhances the acquisition of temporal associative memories, paralleling mechanisms involved in mGluR5 priming of TBS-LTP in the hippocampus.

\section{I-LTD is the underlying metaplastic change in associative learning} The underlying priming-associated metaplastic change that enhances TBS of excitatory synapses in hippocampal neurons is an eCB-mediated depression of inhibitory tone. This change is long-lasting and can be measured in a hippocampal slice as I-LTD (Chevaleyre and Castillo, 2003). To determine whether the same priming train that facilitated LTP also produces I-LTD in CA1 neurons, we made voltage-clamp recordings of isolated IPSCs in the presence of D-APV $(50 \mu \mathrm{M})$ and NBQX (10 $\mu \mathrm{M})$. After collection of a stable baseline of responses, $210 \mathrm{~s}, 10$ $\mathrm{Hz}$ priming trains were delivered. In $\mathrm{Cre}^{-}$animals, there was an immediate reduction in the amplitude of the evoked IPSC that persisted for the duration of the recording, whereas in $\mathrm{Cre}^{+}$animals, there was significantly lower immediate and longer-lasting depression, clearly demonstrating that the priming train does reduce GABAergic synaptic transmission and that this I-LTD requires mGluR5 in CA1 neurons ( $\mathrm{Cre}^{-}: 67.1 \pm 3.8 \%, n=13$ cells from 5 mice; $\mathrm{Cre}^{+}: 84.6 \pm 3.6 \%, n=15$ cells from 5 mice, $\mathrm{K}-\mathrm{S}$ $p<0.05$; Fig. $6 A-C$ ).

In a further set of experiments, we tested the effect of inhibiting MAGL with JZL184 (2 $\mu \mathrm{M})$ on I-LTD. In this case, we reduced priming to single $10 \mathrm{~s}$ train at $10 \mathrm{~Hz}$ so as to not saturate the endocannabinoid effect. In the absence of the JZL184, we observed only small depression (I-LTD: $86.9 \pm 4.2 \%, n=9$; Fig. $6 D)$, whereas in experiments in which JZL184 was present, I-LTD was significantly enhanced $(58.63 \pm 5.81 \%, n=8$; $t$ test, $p<$ $0.01)$. To determine the involvement of mGluR5 in JZL184 enhancement of I-LTD, we repeated these experiments in CA1-ko animals. We found that JZL184 had no effect on inhibitory synapse depression in these experiments, with little or no I-LTD observed in $\mathrm{Cre}^{+}$vehicle-treated slices or $\mathrm{Cre}^{+}$JZL184-treated slices (Fig. 6E). Together, these experiments confirm that the priming train produces LTD of inhibitory neurotransmission, which is dependent on mGluR5 and eCBs. 
A key question is whether this form of metaplasticity occurs in vivo and contributes to the learning. We have demonstrated that the same mechanisms involved in LTP priming also affect temporal associative memory; however, to determine a more direct link between mGluR5-mediated metaplasticity in the CA1 and this form of learning, we examined plasticity ex vivo after training wild-type animals in the trace-conditioning paradigm (using four CS-trace-US pairings). One hour after training, animals were killed to make acute hippocampal slices and recordings were made from CA1 neurons. In animals that had undergone training, we found that the amplitude of I-LTD induced by 2, $10 \mathrm{~s}, 10$ $\mathrm{Hz}$ trains was reduced compared with recordings made from the control group that had been exposed to the conditioning chamber for $10 \mathrm{~min}$ but without foot shocks and tone presentations. (control group: $69.7 \pm 2.5 \%, n=20$ cells from 9 animals; conditioned group: $81.1 \pm 2.9 \%, n=17$ cells from 7 animals; K-S test, $p<0.05$; Fig. $7 A, B$ ). This might suggest that I-LTD occurs in vivo after trace conditioning and causes partial occlusion of the I-LTD induced in ex vivo recordings. In animals that were exposed to only a tone before ex vivo slice recording, we found that the magnitude of I-LTD was equivalent to the naive group (tone group: $70.8 \pm 3.4 \%, n=18$ cells from 7 animals; Fig. $7 C, D)$. Similarly, recordings from animals that were administered AM251 (5.0 mg/kg) before delay conditioning were found to have normal I-LTD (AM251 group: $68.0 \pm 6.6 \%, n=13$ cells from 5 animals; Fig. $7 C, D$ ). In a separate set of recordings, we monitored paired pulse ratios (PPRs) of IPSCs recorded at an interstimulus interval of $100 \mathrm{~ms}$ in CA1 neurons from trained and control animals. Consistent with a decrease in release probability at inhibitory synapses, there was less depression of IPSCs in slices from conditioned animals (PPR100 ms control group: $0.66 \pm 0.02, n=$ 25 cells from 7 animals; PPR100 ms conditioned group: $0.79 \pm$ 0.03, $n=25$ from 4 animals; $t$ test, $p<0.05$; Fig. $7 E$ ).

A persistent suppression of inhibition in vivo would promote LTP of active excitatory synapses in the CA1 and might contribute to consolidation of the memory. To test this idea, in a separate series of experiments, we again trained mice in trace conditioning and $1 \mathrm{~h}$ later made hippocampal sections for ex vivo recording. We found that the magnitude of LTP induced by TBS (with no priming) in CA1 was significantly elevated (165 $\pm 10.1 \%, n=12$ slices from 6 animals) compared with interleaved recordings from control animals $(131 \pm 6.0 \% n=9$ slices from 6 animals; $t$ test, $p<0.05$; Fig. $7 F$ ). In animals that only received a tone before ex vivo recording, the magnitude of LTP was equivalent to the naive condition (tone group: $131.1 \pm 6.9 \%, n=12$ slices from 5 mice; Fig. $7 G$ ). In addition, if animals were administered AM251 $(5.0 \mathrm{mg} / \mathrm{kg}$ ) before conditioning, subsequent measures of TBSLTP were normal (AM251 group: $127.6 \pm 6.5 \%, n=11$ slices from 4 mice; Fig. $7 G$ ) Together, these experiments provide additional support to link metaplastic changes of inhibition in the hippocampus to trace conditioning paradigms and the formation of temporal associative memories.

\section{Discussion}

In vitro studies of metaplasticity have long posited that statedependent mechanisms are critical to plasticity of synaptic connections. Prior activity in a network will greatly influence the future probability of synaptic strengthening (Abraham and Bear, 1996). Similarly, it has been demonstrated in vivo that memories can be primed by prior experience (Parsons and Davis, 2012). Despite this, it has been difficult to demonstrate a direct link between specific forms of metaplasticity that can be observed in vitro and specific forms of learning. Our finding that ablation of
mGluR5 restricted to CA1 neurons disrupted priming of LTP without affecting Hebbian plasticity by itself allowed us to dissect the role of mGluR5 metaplasticity in the CA1. Ablation of mGluR5 in the CA1 had no effect on spatial reference memory, a hippocampal-dependent form of learning that has a clear cellular correlate in Hebbian plasticity (Lynch, 2004). Instead, we found that CA1 mGluR5 is critical for the acquisition of associative memories that have a temporal processing component. CA1-ko animals were impaired in their ability to associate the CS and US when a trace interval of $30 \mathrm{~s}$ was included, but not when CS and US co-terminated or were separated by shorter intervals. Further analysis of mGluR5 priming in vitro demonstrated that CA1 mGluR5 signaling mobilized eCBs and underlay I-LTD, as had been proposed previously (Chevaleyre and Castillo, 2004). Furthermore, we identified the relevant $\mathrm{eCB}$ species mobilized by priming as 2-AG and found that manipulating the accumulation of 2-AG enhanced metaplasticity in vitro and enhanced learning that required temporal processing in vivo. In addition, recordings made from hippocampal slices of mice trained in the acquisition of trace associations had reduced I-LTD, suggesting that undergoing this training may by itself suppress inhibitory neurotransmission in the CA1. In support of a role for trace conditioning priming the hippocampus for plasticity, we also found that in slices taken from mice after training the amplitude of TBS-LTP was enhanced. This study demonstrates a clear role for mGluR5 in regulating inhibitory neurotransmission through mobilization of eCBs, thus priming the $\mathrm{CA} 1$, and this metaplasticity being critical to learning in a temporal associative behavioral task.

Earlier studies using pharmacological approaches or constitutive knock-out have proposed that group $1 \mathrm{mGluRs}$ play a role in Hebbian plasticity (Bashir et al., 1993; Lu et al., 1997); however, the overwhelming weight of evidence demonstrates that mGluR5 is not required for the induction of standard NMDA receptordependent LTP (Fitzjohn et al., 1998; Bortolotto et al., 2005). Our study confirms a primary role for CA1 mGluR5 in metaplasticity by virtue of their ability to mobilize eCBs to induce heterosynaptic I-LTD. There has also been a suggestion that group $1 \mathrm{mGluR}$ priming of LTP involves an inhibition of the postburst afterhyperpolarization (AHP) and increased excitability (Cohen and Abraham, 1996). A subsequent study from the same investigators found that the effects of mGluR activation on cellular excitability and their role in priming plasticity use very different mechanisms (Ireland and Abraham, 2002), suggesting that different populations of receptors may be involved in increasing cellular excitability and priming LTP. These prior studies had used exogenous agonists to activate mGluRs and we found that the synaptic stimulated priming train had no effect on excitability of CA1 pyramidal neurons (data not shown). Therefore, the role of mGluR5 in CA1 neurons seems to be highly specific in mediating I-LTD.

The hippocampus has long been known as an important cortical region for the association of discontiguous events (Wallenstein et al., 1998); however, there are only a few genetic animal models in which disruption of hippocampal function leads to specific alteration in temporal association. Previous studies using CA1-restricted knock-out of genes involved in plasticity have not provided such a specific impairment in temporal associative learning. For example, knock-out of NR1 in CA1 pyramidal cells impairs both spatial reference memory (Tsien et al., 1996a) and temporal memory (Huerta et al., 2000). Therefore, CA1 mGluR5 knock-out mice provide new insight into the temporal coding function of the hippocampus (Rolls and Kesner, 2006) and into the relevance of metaplasticity to learning. Endocannabinoidmediated metaplasticity in the hippocampus is mediated by 
A

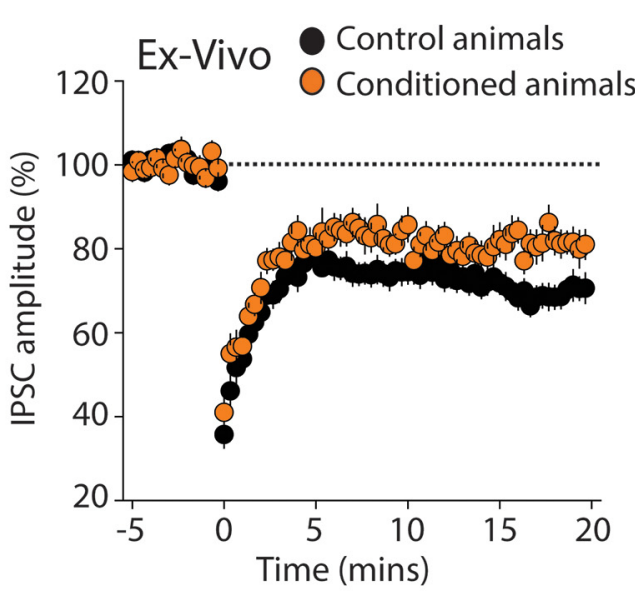

C

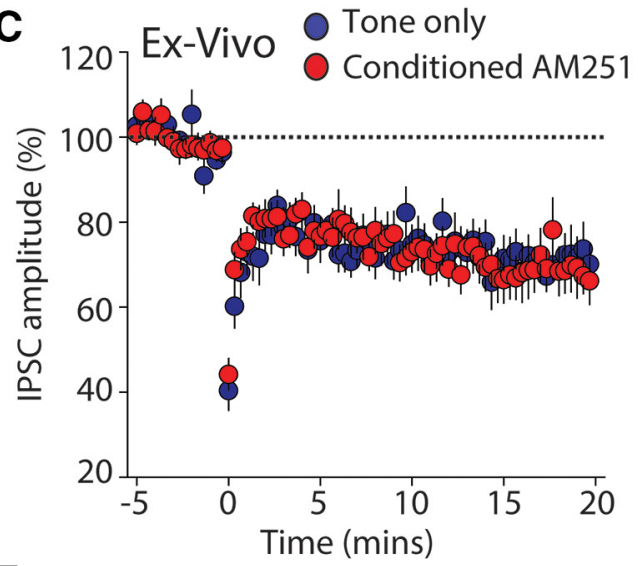

$\mathbf{F}$

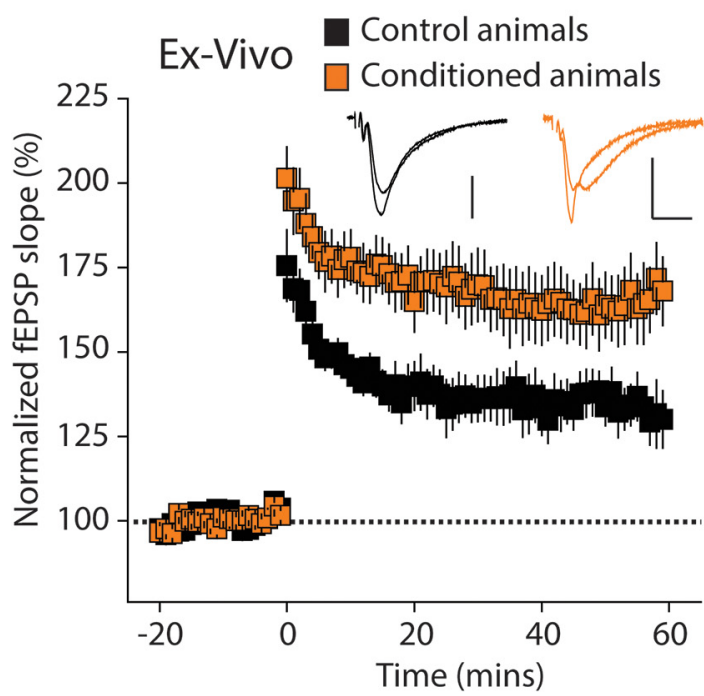

B
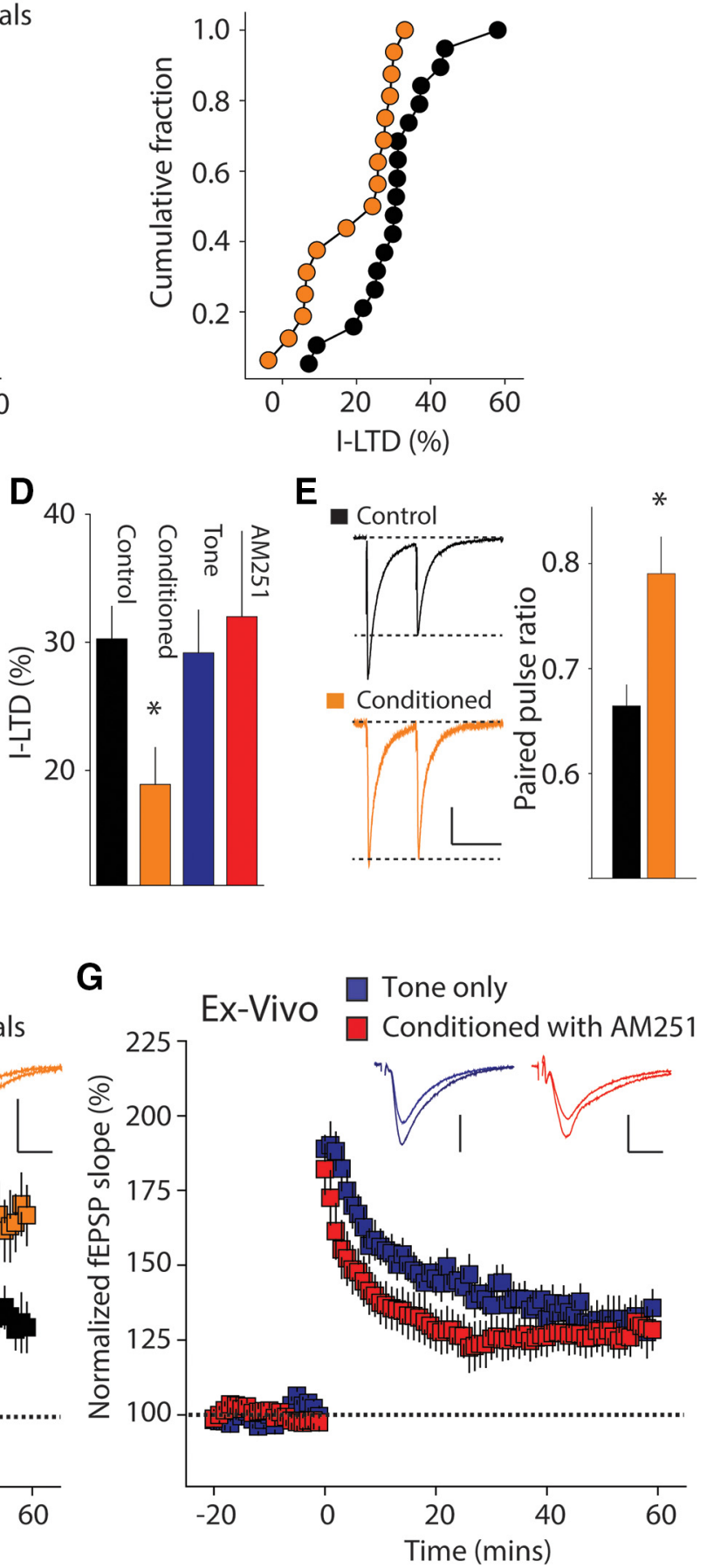

Figure 7. Trace conditioning partially occludes I-LTD and enhances TBS-LTP in the CA1. $A, B$, Time course $(\boldsymbol{A})$ and cumulative probability $(\boldsymbol{B})$ of ex vivo I-LTD experiments. Wild-type animals were trained in trace fear conditioning (conditioned group) or exposed to the conditioning chamber (control group) $1 \mathrm{~h}$ before they were killed for electrophysiological experiments. I-LTD was induced by 2 trains of $10 \mathrm{~s}, 10 \mathrm{~Hz}$ stimulation in slices from control (black squares) and conditioned animals (orange squares). I-LTD was significantly reduced in slices from animals that had undergone training. C, In separate recording in slices from animals exposed to the tone alone or which had been conditioned after IP injection of AM251 (5 mg/kg), I-LTD amplitude was normal. D, Grouped data for all exvivo I-LTD recordings. I-LTD was significantly smaller only in the conditioned animal group. E, Paired pulse ratio of IPSCs at $100 \mathrm{~ms}$ interstimulus intervals. Left, Representative IPSCs from control and conditioned animals. Calibration: $50 \mathrm{pA}, 100 \mathrm{~ms}$. Right, Grouped data from all recordings. F, Time course of TBS-LTP in slices from control and conditioned animals. TBS-LTP was induced without a prior priming train. TBS-LTP is significantly enhanced in the slices from the conditioned animals. Insets show representative traces during baseline and after LTP induction. Calibration: $0.5 \mathrm{mV}, 10 \mathrm{~ms}$. G, TBS-LTP experiments in animals exposed to tone only or in animals conditioned after administration of AM251 had normal levels of LTP. Insets show representative traces from one experiment. Calibration: $0.5 \mathrm{mV}, 10 \mathrm{~ms}$.

GABAergic disinhibition (Chevaleyre and Castillo, 2004; Edwards et al., 2008) and the loss of this control of inhibitory neurotransmission is responsible for the alterations in trace fear learning in the mGluR5 CA1-ko mice. Consistent with our findings, multiple reports have shown that reducing GABAergic in- hibition in the hippocampus by knock-out or mutation of specific $\mathrm{GABA}_{\mathrm{A}} \mathrm{R}$ subunits enhances trace fear conditioning (Crestani et al., 2002; Wiltgen et al., 2005; Moore et al., 2010).

The clearest link we found between temporal associative learning and this form of metaplasticity was in ex vivo experi- 
ments in which I-LTD was partially occluded and TBS-LTP was enhanced in the CA1 after animals that had undergone trace conditioning. Several prior studies have demonstrated that learning can induce LTP-like processes in the hippocampus (Whitlock et al., 2006), neocortex (Rioult-Pedotti et al., 1998; RioultPedotti et al., 2000), and amygdala (McKernan and ShinnickGallagher, 1997; Rogan et al., 1997; Tsvetkov et al., 2002) and experience-dependent potentiation may occlude subsequent induction of LTP in vitro (Rioult-Pedotti et al., 2000; Whitlock et al., 2006). Conversely, in vivo saturation of LTP in specific pathways can disrupt further learning (McNaughton et al., 1986; Moser et al., 1998; Gruart et al., 2006). We did not find an occlusion of LTP in our experiments, but instead an occlusion of I-LTD, suggesting that the CS-trace-US pairing likely produces a widespread depression of inhibition in the hippocampus. Although some excitatory synapses might also be potentiated during the training, this is likely to be only a small fraction of all the synaptic connections in the CA1 and, therefore, LTP was not saturated, as has been reported in some studies. However, a more globalized disinhibition of the hippocampus during acquisition would be permissive to learning in a similar way that priming trains are permissive to TBS-LTP in the slice.

We also found that inhibiting hydrolysis of 2-AG both facilitated the priming effect on TBS-LTP and enhanced acquisition of temporal associative learning. Interestingly, genetic deletion of MAGL, which causes a $>10$-fold increase in 2-AG levels in the brain, also enhances TBS-LTP and increases performance in spatial learning (Pan et al., 2011). Our results provide additional support for the involvement of eCB mobilization through activation of mGluR5 in enhancing the acquisition of a form hippocampal memory. Whether this signaling is specifically used for a certain type of learning or if the effects of loss of this signaling in the CA1-ko mice are only most prominent in a difficult task such as the $30 \mathrm{~s}$ trace association, when disinhibition will facilitate synaptic strengthening more readily, are yet to be clarified. However, we found no other deficits in standard hippocampaldependent learning in these mice; therefore, it is interesting to speculate that the role of this signaling in CA1 is quite selective. In either case, targeting this system either with modulators of eCB signaling or positive modulators of mGluR5 signaling may be useful for enhancing cognition in memory disorders.

Our study provides evidence that metaplasticity in the CA1 of the hippocampus is directly linked to the ability of animals to perform temporal associative learning. The development of these novel mice has provided clarification of the basic roles of mGluR5 in regulating synaptic plasticity, but has also provided new insight into how metaplasticity and I-LTD, which have previously only been studied in vitro, contribute to learning and memory formation in vivo.

\section{References}

Abraham WC, Bear MF (1996) Metaplasticity: the plasticity of synaptic plasticity. Trends Neurosci 19:126-130. CrossRef Medline

Bashir ZI, Bortolotto ZA, Davies CH, Berretta N, Irving AJ, Seal AJ, Henley JM, Jane DE, Watkins JC, Collingridge GL (1993) Induction of LTP in the hippocampus needs synaptic activation of glutamate metabotropic receptors. Nature 363:347-350. CrossRef Medline

Bortolotto ZA, Collett VJ, Conquet F, Jia Z, van der Putten H, Collingridge GL (2005) The regulation of hippocampal LTP by the molecular switch, a form of metaplasticity, requires mGlu5 receptors. Neuropharmacology 49:13-25. CrossRef Medline

Bortolotto ZA, Collett VJ, Conquet F, Jia Z, Collingridge GL (2008) An analysis of the stimulus requirements for setting the molecular switch reveals a lower threshold for metaplasticity than synaptic plasticity. Neuropharmacology 55:454-458. CrossRef Medline
Cai Z, Schools GP, Kimelberg HK (2000) Metabotropic glutamate receptors in acutely isolated hippocampal astrocytes: developmental changes of mGluR5 mRNA and functional expression. Glia 29:70-80. CrossRef Medline

Chevaleyre V, Castillo PE (2003) Heterosynaptic LTD of hippocampal GABAergic synapses: a novel role of endocannabinoids in regulating excitability. Neuron 38:461-472. CrossRef Medline

Chevaleyre V, Castillo PE (2004) Endocannabinoid-mediated metaplasticity in the hippocampus. Neuron 43:871-881. CrossRef Medline

Cohen AS, Abraham WC (1996) Facilitation of long-term potentiation by prior activation of metabotropic glutamate receptors. J Neurophysiol 76: 953-962. Medline

Crestani F, Keist R, Fritschy JM, Benke D, Vogt K, Prut L, Blüthmann H, Möhler H, Rudolph U (2002) Trace fear conditioning involves hippocampal alpha5 GABA(A) receptors. Proc Natl Acad Sci U S A 99:89808985. CrossRef Medline

Edwards DA, Zhang L, Alger BE (2008) Metaplastic control of the endocannabinoid system at inhibitory synapses in hippocampus. Proc Natl Acad Sci U S A 105:8142-8147. CrossRef Medline

Farovik A, Dupont LM, Eichenbaum H (2010) Distinct roles for dorsal CA3 and CA1 in memory for sequential nonspatial events. Learn Mem 17:12-17. CrossRef Medline

Fitzjohn SM, Bortolotto ZA, Palmer MJ, Doherty AJ, Ornstein PL, Schoepp DD, Kingston AE, Lodge D, Collingridge GL (1998) The potent mGlu receptor antagonist LY341495 identifies roles for both cloned and novel mGlu receptors in hippocampal synaptic plasticity. Neuropharmacology 37:1445-1458. CrossRef Medline

Francesconi W, Cammalleri M, Sanna PP (2004) The metabotropic glutamate receptor 5 is necessary for late-phase long-term potentiation in the hippocampal CA1 region. Brain Res 1022:12-18. CrossRef Medline

Gruart A, Muñoz MD, Delgado-García JM (2006) Involvement of the CA3CA1 synapse in the acquisition of associative learning in behaving mice. J Neurosci 26:1077-1087. CrossRef Medline

Hashimotodani Y, Ohno-Shosaku T, Kano M (2007) Presynaptic monoacylglycerol lipase activity determines basal endocannabinoid tone and terminates retrograde endocannabinoid signaling in the hippocampus. J Neurosci 27:1211-1219. CrossRef Medline

Huerta PT, Sun LD, Wilson MA, Tonegawa S (2000) Formation of temporal memory requires NMDA receptors within CA1 pyramidal neurons. Neuron 25:473-480. CrossRef Medline

Ireland DR, Abraham WC (2002) Group I mGluRs increase excitability of hippocampal CA1 pyramidal neurons by a PLC-independent mechanism. J Neurophysiol 88:107-116. Medline

Kathuria S, Gaetani S, Fegley D, Valiño F, Duranti A, Tontini A, Mor M, Tarzia G, La Rana G, Calignano A, Giustino A, Tattoli M, Palmery M, Cuomo V, Piomelli D (2003) Modulation of anxiety through blockade of anandamide hydrolysis. Nat Med 9:76-81. CrossRef Medline

Kesner RP, Hunsaker MR, Gilbert PE (2005) The role of CA1 in the acquisition of an object-trace-odor paired associate task. Behav Neurosci 119: 781-786. CrossRef Medline

Long JZ, Li W, Booker L, Burston JJ, Kinsey SG, Schlosburg JE, Pavón FJ, Serrano AM, Selley DE, Parsons LH, Lichtman AH, Cravatt BF (2009) Selective blockade of 2-arachidonoylglycerol hydrolysis produces cannabinoid behavioral effects. Nat Chem Biol 5:37-44. CrossRef Medline

Lu YM, Jia Z, Janus C, Henderson JT, Gerlai R, Wojtowicz JM, Roder JC (1997) Mice lacking metabotropic glutamate receptor 5 show impaired learning and reduced CA1 long-term potentiation (LTP) but normal CA3 LTP. J Neurosci 17:5196-5205. Medline

Lynch MA (2004) Long-term potentiation and memory. Physiol Rev 84:87136. CrossRef Medline

McEchron MD, Bouwmeester H, Tseng W, Weiss C, Disterhoft JF (1998) Hippocampectomy disrupts auditory trace fear conditioning and contextual fear conditioning in the rat. Hippocampus 8:638-646. CrossRef Medline

McKernan MG, Shinnick-Gallagher P (1997) Fear conditioning induces a lasting potentiation of synaptic currents in vitro. Nature 390:607-611. CrossRef Medline

McNaughton BL, Barnes CA, Rao G, Baldwin J, Rasmussen M (1986) Longterm enhancement of hippocampal synaptic transmission and the acquisition of spatial information. J Neurosci 6:563-571. Medline

Moore MD, Cushman J, Chandra D, Homanics GE, Olsen RW, Fanselow MS (2010) Trace and contextual fear conditioning is enhanced in mice lack- 
ing the alpha4 subunit of the GABA(A) receptor. Neurobiol Learn Mem 93:383-387. CrossRef Medline

Mor M, Rivara S, Lodola A, Plazzi PV, Tarzia G, Duranti A, Tontini A, Piersanti G, Kathuria S, Piomelli D (2004) Cyclohexylcarbamic acid 3'- or 4'substituted biphenyl-3-yl esters as fatty acid amide hydrolase inhibitors: synthesis, quantitative structure-activity relationships, and molecular modeling studies. J Med Chem 47:4998-5008. CrossRef Medline

Moser EI, Krobert KA, Moser MB, Morris RG (1998) Impaired spatial learning after saturation of long-term potentiation. Science 281:20382042. CrossRef Medline

Neyman S, Manahan-Vaughan D (2008) Metabotropic glutamate receptor 1 (mGluR1) and 5 (mGluR5) regulate late phases of LTP and LTD in the hippocampal CA1 region in vitro. Eur J Neurosci 27:1345-1352. CrossRef Medline

Pan B, Wang W, Zhong P, Blankman JL, Cravatt BF, Liu QS (2011) Alterations of endocannabinoid signaling, synaptic plasticity, learning, and memory in monoacylglycerol lipase knock-out mice. J Neurosci 31: 13420-13430. CrossRef Medline

Parsons RG, Davis M (2012) A metaplasticity-like mechanism supports the selection of fear memories: role of protein kinase a in the amygdala. J Neurosci 32:7843-7851. CrossRef Medline

Quinn JJ, Oommen SS, Morrison GE, Fanselow MS (2002) Post-training excitotoxic lesions of the dorsal hippocampus attenuate forward trace, backward trace, and delay fear conditioning in a temporally specific manner. Hippocampus 12:495-504. CrossRef Medline

Rioult-Pedotti MS, Friedman D, Hess G, Donoghue JP (1998) Strengthening of horizontal cortical connections following skill learning. Nat Neurosci 1:230-234. CrossRef Medline

Rioult-Pedotti MS, Friedman D, Donoghue JP (2000) Learning-induced LTP in neocortex. Science 290:533-536. CrossRef Medline

Rogan MT, Stäubli UV, LeDoux JE (1997) Fear conditioning induces associative long-term potentiation in the amygdala. Nature 390:604-607. CrossRef Medline

Rolls ET, Kesner RP (2006) A computational theory of hippocampal function, and empirical tests of the theory. Prog Neurobiol 79:1-48. CrossRef Medline
Shapiro ML, Eichenbaum H (1999) Hippocampus as a memory map: synaptic plasticity and memory encoding by hippocampal neurons. Hippocampus 9:365-384. CrossRef Medline

Tanimura A, Yamazaki M, Hashimotodani Y, Uchigashima M, Kawata S, Abe M, Kita Y, Hashimoto K, Shimizu T, Watanabe M, Sakimura K, Kano M (2010) The endocannabinoid 2-arachidonoylglycerol produced by diacylglycerol lipase alpha mediates retrograde suppression of synaptic transmission. Neuron 65:320-327. CrossRef Medline

Tsien JZ, Huerta PT, Tonegawa S (1996a) The essential role of hippocampal CA1 NMDA receptor-dependent synaptic plasticity in spatial memory. Cell 87:1327-1338. CrossRef Medline

Tsien JZ, Chen DF, Gerber D, Tom C, Mercer EH, Anderson DJ, Mayford M, Kandel ER, Tonegawa S (1996b) Subregion- and cell type-restricted gene knockout in mouse brain. Cell 87:1317-1326. CrossRef Medline

Tsvetkov E, Carlezon WA, Benes FM, Kandel ER, Bolshakov VY (2002) Fear conditioning occludes LTP-induced presynaptic enhancement of synaptic transmission in the cortical pathway to the lateral amygdala. Neuron 34:289-300. CrossRef Medline

van Hooft JA, Giuffrida R, Blatow M, Monyer H (2000) Differential expression of group I metabotropic glutamate receptors in functionally distinct hippocampal interneurons. J Neurosci 20:3544-3551. Medline

Wallenstein GV, Eichenbaum H, Hasselmo ME (1998) The hippocampus as an associator of discontiguous events. Trends Neurosci 21:317-323. CrossRef Medline

Whitlock JR, Heynen AJ, Shuler MG, Bear MF (2006) Learning induces long-term potentiation in the hippocampus. Science 313:1093-1097. CrossRef Medline

Wiltgen BJ, Sanders MJ, Ferguson C, Homanics GE, Fanselow MS (2005) Trace fear conditioning is enhanced in mice lacking the delta subunit of the GABAA receptor. Learn Mem 12:327-333. CrossRef Medline

$\mathrm{Xu} \mathrm{J,} \mathrm{Zhu} \mathrm{Y,} \mathrm{Contractor} \mathrm{A,} \mathrm{Heinemann} \mathrm{SF} \mathrm{(2009)} \mathrm{mGluR5} \mathrm{has} \mathrm{a} \mathrm{critical} \mathrm{role}$ in inhibitory learning. J Neurosci 29:3676-3684. CrossRef Medline

Zhao MG, Toyoda H, Ko SW, Ding HK, Wu LJ, Zhuo M (2005) Deficits in trace fear memory and long-term potentiation in a mouse model for fragile X syndrome. J Neurosci 25:7385-7392. CrossRef Medline 